\title{
Impacts of droughts on carbon sequestration by China's terrestrial ecosystems from 2000 to 2011
}

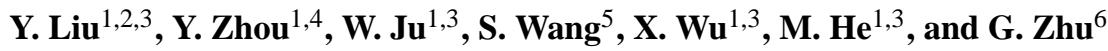 \\ ${ }^{1}$ Jiangsu Provincial Key Laboratory of Geographic Information Science and Technology, Nanjing University, Nanjing, \\ 210023, China \\ ${ }^{2}$ Jiangsu Key Laboratory of Agricultural Meteorology, College of Applied Meteorology, Nanjing University of Information \\ Science and Technology, Nanjing, 210044, China \\ ${ }^{3}$ International Institute for Earth System Sciences, Nanjing University, Nanjing, 210023, China \\ ${ }^{4}$ School of Geographic and Oceanographic Sciences, Nanjing University, Nanjing, 210023, China \\ ${ }^{5}$ Key Laboratory of Ecosystem Network Observation and Modeling, Institute of Geographic Sciences and Natural Resources \\ Research, Chinese Academy of Sciences, Beijing, 100101, China \\ ${ }^{6}$ Department of Geography, Minjiang University, Fuzhou, 350108, China
}

Correspondence to: W. Ju (juweimin@nju.edu.cn)

Received: 23 October 2013 - Published in Biogeosciences Discuss.: 6 November 2013

Revised: 26 March 2014 - Accepted: 26 March 2014 - Published: 16 May 2014

\begin{abstract}
In recent years, China's terrestrial ecosystems have experienced frequent droughts. How these droughts have affected carbon sequestration by the terrestrial ecosystems is still unclear. In this study, the process-based Boreal Ecosystem Productivity Simulator (BEPS) model, driven by remotely sensed vegetation parameters, was employed to assess the effects of droughts on net ecosystem productivity (NEP) of terrestrial ecosystems in China from 2000 to 2011. Droughts of differing severity, as indicated by a standard precipitation index (SPI), hit terrestrial ecosystems in China extensively in 2001, 2006, 2009, and 2011. The national total annual NEP exhibited the slight decline of $-11.3 \mathrm{Tg} \mathrm{C} \mathrm{yr}^{-2}$ during the aforementioned years of extensive droughts. The NEP reduction ranged from $61.1 \mathrm{Tg}$

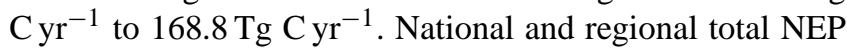
anomalies were correlated with the annual mean SPI, especially in Northwest China, North China, Central China, and Southwest China. The reductions in annual NEP in 2001 and 2011 might have been caused by a larger decrease in annual gross primary productivity (GPP) than in annual ecosystem respiration (ER). The reductions experienced in 2009 might be due to a decrease in annual GPP and an increase in annual ER, while reductions in 2006 could stem from a larger increase in ER than in GPP. The effects of droughts on NEP lagged up to 3-6 months, due to different responses of
\end{abstract}

GPP and ER. In eastern China, where is humid and warm, droughts have predominant and short-term lagged influences on NEP. In western regions, cold and arid, the drought effects on NEP were relatively weaker but prone to lasting longer.

\section{Introduction}

The exchange of carbon dioxide $\left(\mathrm{CO}_{2}\right)$ between land and the atmosphere is important to the global carbon cycle (Arnone et al., 2008; Schwalm et al., 2010a). Carbon sequestration by terrestrial ecosystems is affected by a number of factors, including climate, atmospheric $\mathrm{CO}_{2}$ concentration, nitrogen deposition, land cover types, and land use change. Extreme climate events, such as drought, could substantially affect ecosystem carbon fluxes and lead to significant inter-annual variability in the regional and even global terrestrial carbon budget (Running, 2008; Xiao et al., 2011). In contrast to gradual climate change, carbon sequestration by terrestrial ecosystems might be strongly impacted by droughts in a relatively short period. Both gross primary productivity (GPP) and ecosystem respiration (ER), which releases carbon to the atmosphere, significantly influence carbon sequestration (Baldocchi, 2005; Meir et al., 2008; Schwalm et al., 2010a; van der Molen et al., 2011). 
Particularly at the middle and high latitudes, droughts of greater frequency and severity are projected to occur in the future under climate change characterized by decreasing precipitation and increasing temperature (IPCC, 2007; Dai, 2013). Given the strong link between the carbon and water cycles (Law et al., 2002), the effects of droughts on terrestrial carbon sequestration have been widely investigated in recent years (Cox et al., 2000; Zeng et al., 2004; Ciais et al., 2005; Wu and Chen, 2013). Models and remote sensing are effective tools for assessing how terrestrial carbon cycles respond to droughts on both regional and global scales (Chen et al., 2012a). Several modeling studies have recently been conducted to assess the impact of droughts on the productivity and carbon budget of terrestrial ecosystems for western North America (Schwalm et al., 2012), the southern United States (Chen et al., 2012a), Europe (Ciais et al., 2005; Reichstein et al., 2007; Vetter et al., 2008), Amazonia (Phillips et al., 2009; Potter et al., 2011; Nunes et al., 2012), East Asia (Saigusa et al., 2010; Xiao et al., 2009), the Northern Hemisphere mid-latitudes (Zeng et al., 2005), and the globe (Zhao and Running, 2010; Chen et al., 2013). All these studies indicated that droughts significantly influence the terrestrial carbon cycle and might even cause terrestrial ecosystems to shift from carbon sinks to carbon sources (Chen et al., 2013; Ponce Campos et al., 2013; Piao et al., 2013).

China has the third largest land area in the world, with diverse climate and biome types (Cao et al., 2003). The country's terrestrial ecosystems play an important role in the terrestrial carbon sink for the entire globe. Therefore, in studying the past, current, and future roles of terrestrial ecosystems in retarding not only the increase in atmospheric $\mathrm{CO}_{2}$ concentration but overall climate change as well, the spatial and temporal variations in China's terrestrial carbon budget must be quantified (Mu et al., 2008; Piao et al., 2009a; Tian et al., 2011a). The absorption of carbon by China's terrestrial ecosystems is limited by water availability, especially in vast arid and semiarid regions (Hu et al., 2010; Yi et al., 2010; Yu et al., 2013). Many severe droughts have occurred in China since the 1950s (Zou et al., 2005; Zhai et al., 2010), especially in the first 10 years of this century (Piao et al., 2009b; Qin et al., 2010; Lu et al., 2011; Wang et al., 2011; Wu et al., 2011). These droughts have significantly influenced the terrestrial carbon cycle on regional and national scales (Xiao et al., 2009).

Several studies have investigated the impact of droughts on China's regional and national terrestrial carbon budgets. Using chronologies of tree-ring width along with the Terrestrial Ecosystem Model (TEM), Xiao et al. (2009) discovered that severe and extended droughts during the 20th century substantially reduced ecosystem carbon sequestration, and may have even changed terrestrial ecosystems from carbon sinks to carbon sources. Using the Carnegie-AmesStanford Approach (CASA) model, Pei et al. (2013) showed that some droughts in the period from 2001 to 2010 substantially reduced China's countrywide net primary produc- tivity (NPP), whereas others did not. Utilizing the Moderate Resolution Imaging Spectroradiometer (MODIS) GPP and NPP products, Zhang et al. (2012a) reported that the 2010 spring drought caused detectable reductions of GPP and NPP in southwestern China. Using the light use efficiency models CASA, MODIS-GPP, and Eddy Covariance Light Use Efficiency (EC-LUE), along with the dynamic Integrated Biosphere Simulator (IBIS) vegetation model, Yuan et al. (2013) found that the carbon sink over North China declined by $0.011 \mathrm{Pg} \mathrm{Cyr}^{-1}$ during the 1999-2011 drought period. However, these studies mainly focused on the influence of droughts on GPP and NPP. The effect of droughts on national net carbon exchange between the atmosphere and terrestrial ecosystems has not yet been thoroughly explored.

This study assesses the impact of droughts on the net ecosystem productivity (NEP) of China's terrestrial ecosystems from 2000 to 2011. This assessment is based on a process-based Boreal Ecosystem Productivity Simulator (BEPS) model, which is driven by climate data and remotely sensed leaf area index (LAI) data. The objectives of this paper are to (1) characterize the spatial and temporal variations of droughts from 2000 to 2011 based on the standard precipitation index (SPI), (2) evaluate the regional and national response of NEP to drought, and (3) assess the accumulative and lagged effects of droughts on ecosystem carbon sequestration.

\section{Data and methods}

\subsection{Model description}

The tool used in this study is the BEPS model (Liu et al., 1997), which originally stemmed from the FOREST BioGeochemical Cycles (FOREST-BGC) model (Running and Coughlan, 1988). This model includes photosynthesis, energy balance, hydrological, and soil biogeochemical modules (Ju et al., 2010a). Stratifying canopies into sunlit and shaded leaves, it incorporates a new temporal and spatial scaling scheme (Chen et al., 1999) into Farquhar's instantaneous leaf biochemical model (Farquhar et al., 1980) to calculate daily carbon fixation. Although initially developed to simulate NPP in boreal ecosystems in Canada, the BEPS model has been improved in many ways and widely used to estimate regional terrestrial carbon and water fluxes in China (Sun et al., 2004; Wang et al., 2005; Feng et al., 2007; Ju et al., 2010b; Liu et al., 2013a, b), North America (Liu et al., 1999; Ju et al., 2006; Sonnentag et al., 2008; Sprintsin et al., 2012; Zhang et al., 2012b), Europe (Wang et al., 2004), East Asia (Matsushita and Tamura, 2002; Zhang et al., 2010, 2012c), and the globe (Chen et al., 2012b). Previous validations proved that the BEPS model was able to simulate the carbon and water fluxes well at various spatial and temporal scales for different ecosystems (Wang et al., 2005; Ju et 
al., 2006; Mo et al., 2008; Schwalm et al., 2010b; Liu et al., 2013a, b).

Details about the BEPS model have been fully described elsewhere (Liu et al., 1997, 2003; Chen et al., 1999, 2005; Ju et al., 2006). Only some of the major methodologies related to the calculation of NEP are summarized here.

\subsubsection{NEP calculation}

NEP is calculated as the difference between photosynthesis and respiration:

$\mathrm{NEP}=\mathrm{GPP}-R_{\mathrm{m}}-R_{\mathrm{g}}-R_{\mathrm{h}}$,

where $R_{\mathrm{h}}$ is the heterotrophic respiration, and maintenance respiration $\left(R_{\mathrm{m}}\right)$ and growth respiration $\left(R_{\mathrm{g}}\right)$ are the components of the autotrophic respiration. $R_{\mathrm{g}}$ is assumed to be $25 \%$ of GPP and $R_{\mathrm{m}}$ is calculated as a function of biomass, temperature, and reference respiratory rate at $25^{\circ} \mathrm{C}$ (Ju et al., 2006; Mo et al., 2008):

$R_{\mathrm{m}}=\sum_{i=1}^{1} R_{\mathrm{m}, i}=\sum_{i=1}^{1} M_{i} r_{\mathrm{m}, i} Q_{10}^{\left(T-T_{\mathrm{b}}\right) / 10}$

where $M_{i}$ is the biomass carbon content $\left(\mathrm{kg} \mathrm{m}^{-2}\right)$; subscript $i$ denotes leaf, stem coarse root, and fine root carbon pools, respectively; $r_{\mathrm{m}, i}$ is the respiration rate at a base temperature $T_{\mathrm{b}}$, set as $15^{\circ} \mathrm{C} ; T$ is the temperature.

The BEPS model simulates the dynamics of soil carbon using methodology adopted from the CENTURY model (Parton et al., 1993). $R_{\mathrm{h}}$ is the total carbon released from five litter carbon pools: surface structural, surface metabolic, soil structural, soil metabolic and coarse woody and from four soil carbon pools: surface and soil microbes, slow, and passive (Ju et al., 2006; Mo et al., 2008):

$R_{\mathrm{h}}=\sum_{j=1}^{9} \tau_{j} k_{j} C_{j}$,

where $\tau_{j}$ is the prescribed respiration coefficient of pool $j ; k_{j}$ the decomposition rate of pool $j$, which equals the prescribed maximum decomposition rate down-scaled according to soil temperature, water content, texture, and lignin content; and $C_{j}$ is the size of pool $j$, updated for each time step.

In the BEPS model, photosynthesis rate is positively related to stomatal conductance, which is regulated by the soil water availability. Drought causes a reduction in stomatal conductance, and subsequent decreases in GPP and $R_{\mathrm{g}} . R_{\mathrm{m}}$ is positively and linearly linked with biomass (Eq. 2). Longterm droughts might lead to decreases in biomass and $R_{\mathrm{m}}$. As droughts become more severe, GPP, $R_{\mathrm{m}}$, and $R_{\mathrm{g}}$ will decrease more sharply. $R_{\mathrm{h}}$ is a function of the abiotic factors of soil temperature and soil moisture, the size of various soil carbon pools, and the inherent maximum rate of these pools. The response of $R_{\mathrm{h}}$ to soil water content (SWC) is inversely parabolic. It deceases with the departure of SWC from an optimal value (typically $60 \%$ of porosity). Droughts normally enhance $R_{\mathrm{h}}$ in areas where SWC is usually above $60 \%$ of porosity but limit $R_{\mathrm{h}}$ in areas where SWC is usually below $60 \%$ of porosity. Such a decrease in respiration caused by droughts has been confirmed by flux measurements (Barr et al., 2004; Yan et al., 2013). Therefore, the response to droughts of NEP simulated by BEPS is not straightforward, but depends on the relative changes of GPP, $R_{\mathrm{g}}, R_{\mathrm{m}}$, and $R_{\mathrm{h}}$ along with the severity, duration and timing of droughts.

\subsubsection{Regulation of stomatal conductance by soil water content}

In BEPS, the Jarvis model simulates stomatal conductance of sunlit and shaded leaves (Jarvis, 1976) while temperature, atmospheric vapor pressure deficit, photosynthetic photon flux density, and SWC regulate the conductance. Assuming that vegetation optimizes soil water uptake, the soil water scalar, $f_{\mathrm{w}}$, is determined from

$f_{\mathrm{w}}=\sum_{i=1}^{n} f_{\mathrm{w}, \mathrm{i}} \beta_{i}$,

where $f_{\mathrm{w}, i}$ is the soil water stress factor in layer $i$, and $\beta_{i}$ is the weight of layer $i$ expressed as a function of soil water availability and root abundance (Ju et al., 2006):

$\beta_{i}=\frac{r_{i} f_{\mathrm{w}, i}}{\sum_{i=1}^{n} r_{i} f_{\mathrm{w}, i}}$,

where $r_{i}$ is the root fraction within layer $i$ as determined from Zhang and Wegehenkel (2006). The term $f_{\mathrm{w}, i}$ in layer $i$ is calculated as a function of volumetric SWC, wilting point, field capacity, and porosity of soil layer $i$ (Chen et al., 2005; Ju et al., 2010b).

\subsection{Data used}

Both spatially variant and invariant data sets drive the BEPS model. Atmospheric $\mathrm{CO}_{2}$ concentration is assumed to be spatially homogenous. The spatially variant inputs into the BEPS include:

1. Remote sensing data: These include yearly MODIS land cover data sets (MCD12Q1 V051) from 2001 to 2010 (Friedl et al., 2010) and 8-day LAI from 2000 to 2011. The LAI data set was inverted using the MODIS reflectance product (MOD09A1 V05) and an algorithm based on the 4-scale geometric optical model (Deng et al., 2006; Liu et al., 2012). Previous studies have shown that LAI inverted using this algorithm is superior to the existing MODIS product (Pisek et al., 2007; Garrigues et al., 2008).

2. Meteorological data: Using the inverse distance weighted (IDW) method, the incoming solar radiation required to force the BEPS model along with daily 
maximum and minimum air temperatures, precipitation, and relative humidity were interpolated from observations at 753 basic meteorological stations across China. In the interpolation of temperatures, a lapse rate of $6^{\circ} \mathrm{C}$ per $1000 \mathrm{~m}$ was assumed. Incoming solar radiation is not observed at all meteorological stations, so this factor was estimated according to measurements of sunshine duration at these stations (Ju et al., 2010b).

3. Soil data: The volumetric fractions of clay, sand and silt were interpolated from the soil texture maps developed by Shangguan et al. (2012) on the basis of the $1: 1000000$ scale soil map of China and 8595 soil profiles recorded in the second national soil survey data set. These clay, sand, and silt fractions were used to estimate hydrological parameters, including the wilting point (water potential at $1500 \mathrm{kPa}$ ), field capacity (water potential at $33 \mathrm{kPa}$ ), porosity, saturated hydrological conductivity, and air entry water potential.

\subsection{Drought assessment}

Although a variety of indices assess drought severity (Mishra and Singh, 2010; Dai, 2011), the SPI has commonly been used owing to its simplicity, temporal flexibility, and spatial consistency (Hayes et al., 1999; Chen et al., 2012a). Its effectiveness in monitoring droughts in China has been demonstrated by recent studies (Zhai et al., 2010; He et al., 2011; Pei et al., 2013; Zhang and Jia, 2013). SPI is computed by fitting historical precipitation data to a Gamma probability distribution function over a specific time period, and then transforming the Gamma distribution to a standardized normal distribution with a mean of zero and a variance of one (Ji and Peters, 2003). The frequencies of different drought classifications for any timescale and any location are consistent (McKee et al., 1993; Hayes et al., 1999). SPI could be calculated for any duration of interest. For example, SPI was computed at timescales of 1, 2, 3, 6, 9, and 12 months by Jain et al. (2010) and at timesscales of 1, 3, 6, 9, and 12 months by Pei et al. (2013).

In this study, $L(L=1,3,6,9,12)$ month SPI was calculated for a given month using monthly precipitation data in the current and previous $(L-1)$ months, spanning the period from 1970 to 2011, to indicate droughts. Following McKee et al. (1993) and the China Meteorological Administration's drought classification standard (Zhang et al., 2011), droughts in a given year were classified into 9 categories, according to the 12-month SPIs through the end of December (Table 1).

\subsection{Assessment of carbon flux anomaly}

The NEP anomaly caused by droughts was assessed using a standardized anomaly index (SAI) that has been used by others (Peters et al., 2002; Lotsch et al., 2005;
Table 1. Drought classification based on SPI values.

\begin{tabular}{ll}
\hline SPI values & Drought category \\
\hline$\geq 2.00$ & Extreme wet \\
1.50 to 1.99 & Severe wet \\
1.00 to 1.49 & Moderate wet \\
0.50 to 0.99 & Mild wet \\
-0.49 to 0.49 & Near normal \\
-0.99 to -0.50 & Mild drought \\
-1.49 to -1.00 & Moderate drought \\
-1.99 to -1.50 & Severe drought \\
$\leq-2.0$ & Extreme drought \\
\hline
\end{tabular}

Xu et al., 2012; Pei et al., 2013):

$\operatorname{NEP}_{\mathrm{SAI}}(i)=[\mathrm{NEP}(i)-\operatorname{Mean}(\mathrm{NEP})] / \operatorname{Std}(\mathrm{NEP})$,

where $\mathrm{NEP}_{\mathrm{SAI}}(i)$ is the NEP anomaly for year $i, \mathrm{NEP}(i)$ is the NEP in year $i$, and Mean(NEP) and Std(NEP) are, respectively, the mean and standard deviation of the annual NEP from 2000 to 2011.

The carbon flux anomalies were classified into five categories: near normal ( $|\mathrm{SAI}| \leq 0.5)$, slightly anomalous $(0.5<|\mathrm{SAI}| \leq 1)$, moderately anomalous $(1<|\mathrm{SAI}| \leq$ $1.5)$, severely anomalous $(1.5<|\mathrm{SAI}| \leq 2)$, and extremely anomalous $(\mid \mathrm{SAI}>2)$. GPP $\left(\mathrm{GPP}_{\mathrm{SAI}}\right)$ and $\mathrm{ER}\left(\mathrm{ER}_{\mathrm{SAI}}\right)$ anomalies were assessed in the same way.

\subsection{Assessment of accumulative lagged effects of droughts on carbon sequestration}

The accumulative lagged effects of droughts on carbon sequestration were assessed using correlations between

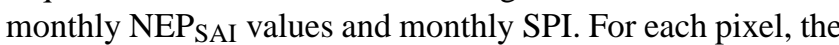
correlation coefficient is calculated as follows:

$R(m, L)=\frac{\sum_{n=1}^{12}\left[\mathrm{NEP}_{\mathrm{SAI}}(m, n)-\overline{\mathrm{NEP}_{\mathrm{SAI}}(m)}\right][\mathrm{SPI}(m, L, n)-\overline{\mathrm{SPI}(m, L)}]}{\sqrt{\sum_{n=1}^{12}\left[\mathrm{NEP}_{\mathrm{SAI}}(m, n)-\overline{\mathrm{NEP}_{\mathrm{SAI}}(m)}\right]^{2}} \sqrt{\sum_{n=1}^{12}[\mathrm{SPI}(m, L, n)-\overline{\mathrm{SPI}(m, L)}]^{2}}}$,

where $R(m, L)$ is the correlation coefficient between NEPSAI and SPI in month $m$ at a given value $L(L=1,3,6,9,12)$ for a specific pixel, $\operatorname{NEP}_{\mathrm{SAI}}(m, n)$ is the $\mathrm{NEP}_{\mathrm{SAI}}$ value in month $m$ of year $n, \overline{\mathrm{NEP}} \mathrm{SAI}(m)$ is the average of $\mathrm{NEP}_{\mathrm{SAI}}$ in month $m$ over 12 years, $\operatorname{SPI}(m, L, n)$ is the SPI value for a given $L$ in month $m$ of year $n$, and $\overline{\operatorname{SPI}(m, L)}$ is the average of SPI $(m, L)$ values over 12 years. A value of $L$ producing the largest $R(m, L)$ indicates that droughts have the strongest accumulative lagged effect up to $L$ months on NEP.

Equations (6) and (7) were applied for each grid cell to analyze the effect of droughts on NEP. China was divided into nine climatic zones (Piao et al., 2009a), displayed in Fig. 1, to demonstrate spatial and temporal patterns of droughts and the terrestrial carbon cycle responses better. 


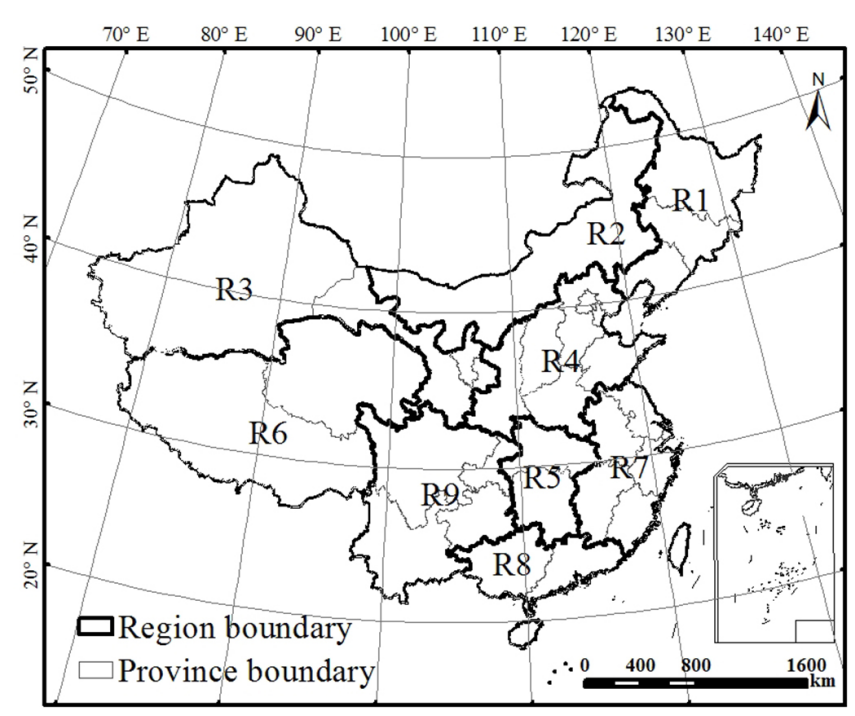

Fig. 1. Spatial distribution of the nine sub-regions in China. Northeast China (R1) (Heilongjiang, Jilin, Liaoning), Inner Mongolia (R2), Northwest China (R3) (Gansu, Ningxia, Xinjiang), North China (R4) (Beijing, Hebei, Henan, Shandong, Shanxi, Shaanxi, Tianjin), Central China (R5) (Hubei, Hunan), Tibetan Plateau (R6) (Qinghai, Tibet), Southeast China (R7) (Anhui, Fujian, Jiangsu, Jiangxi, Shanghai, Taiwan, Zhejiang), South China (R8) (Guangdong, Guangxi, Hainan, Hongkong, Macao), and Southwest China (R9) (Guizhou, Sichuan, Yunnan, Chongqing).

\section{Results}

\subsection{Spatial and temporal variations of droughts in China during the 2000-2011 period}

Figure 2 shows the national means of annual SPI (the 12month SPIs from January through December) in China for the period from 1970 to 2011 , indicating that more droughts occurred during the period from 2000 to 2011 than during the previous three decades. The national annual mean SPI was below zero in 2000, 2001, 2004, 2006, 2009, and 2011. It was even less than -0.20 in 2001, 2006, 2009, and 2011, indicating that China experienced extensive droughts in those years. In 2001 and 2009, areas affected by droughts of various categories accounted for 46.9 and $48.8 \%$ of the total national land area, respectively. Droughts in 2001 and 2011 were more serious, with more than $20 \%$ of the total national area affected by moderate, severe, and extreme droughts (Fig. 3).

Differences in drought severity and drought areas became distinguishable in 2001, 2006, 2009, and 2011. In 2001, droughts occurred in all regions except the Tibetan Plateau, South and Southwest China (Fig. 4). Moderate and severe droughts mainly affected areas in Northeast China, Inner Mongolia, North China, and Central China. The drought in 2011 was recognized as the most serious one in the past 60 years (Sun and Yang, 2012). Vast areas of Southwest, Central, South, and Southeast China experienced moderate

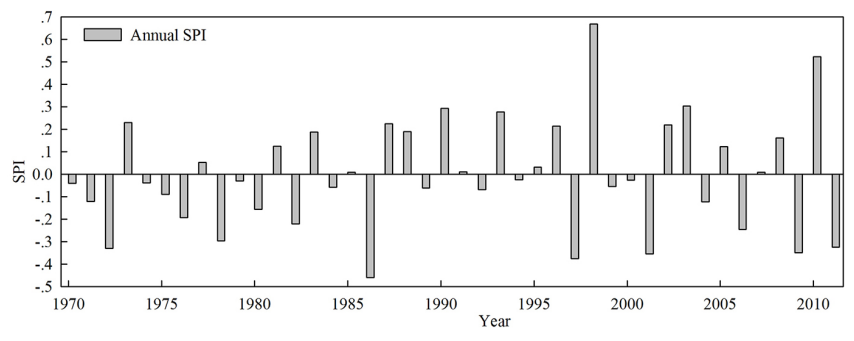

Fig. 2. National mean of annual SPI in China from 1970 to 2011.

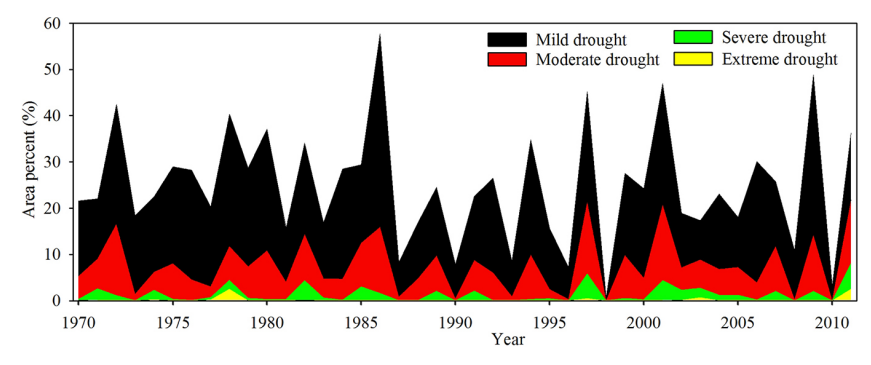

Fig. 3. Percentages of areas hit by different severities of droughts from 1970 to 2011.

to extreme droughts. Extreme droughts affected the Yunnan, Guizhou, and Hunan provinces.

Though droughts also occurred widely throughout China in 2009, the severity was mostly mild to moderate (Gao and Yang, 2009; Lu et al., 2011; Barriopedro et al., 2012). Moderate droughts mainly occurred in the southern parts of both Southwest China and the Tibetan Plateau. In 2006, droughts were mostly mild (Fig. 3), with moderate drought occurring only near Chongqing (Wang et al., 2011; Wu et al., 2011).

\subsection{Response of carbon sequestration to droughts}

\subsubsection{Response of total national carbon sequestration to droughts}

Figure 5 shows the annual anomalies of total national NEP from the multiyear mean over the period from 2000 to 2011. During the past 12 years, the total national NEP has exhibited the slightly decreasing average rate of $-11.3 \mathrm{Tg} \mathrm{C} \mathrm{yr}^{-2}$. This decline was mainly caused by significant decreases in NEP in 2001, 2006, 2009, and 2011. In these four typical drought years, national NEP totals decreased, respectively, by 62.9 , 88.0, 168.8, and $61.1 \mathrm{Tg} \mathrm{C} \mathrm{yr}^{-1}$. The annual anomalies of national total NEP were correlated with national means of annual SPI (12-month SPI through the end of December) $(r=0.54, p=0.06)$. The main drivers for NEP reductions varied during the study years. Annual total GPP and ER both decreased in 2001 and 2011 in comparison to 12-year means. The larger decrease in annual GPP than annual ER significantly reduced total annual NEP in these two years. In 2006, the national total of annual GPP increased slightly, while the national total of annual ER increased on a larger scale, 

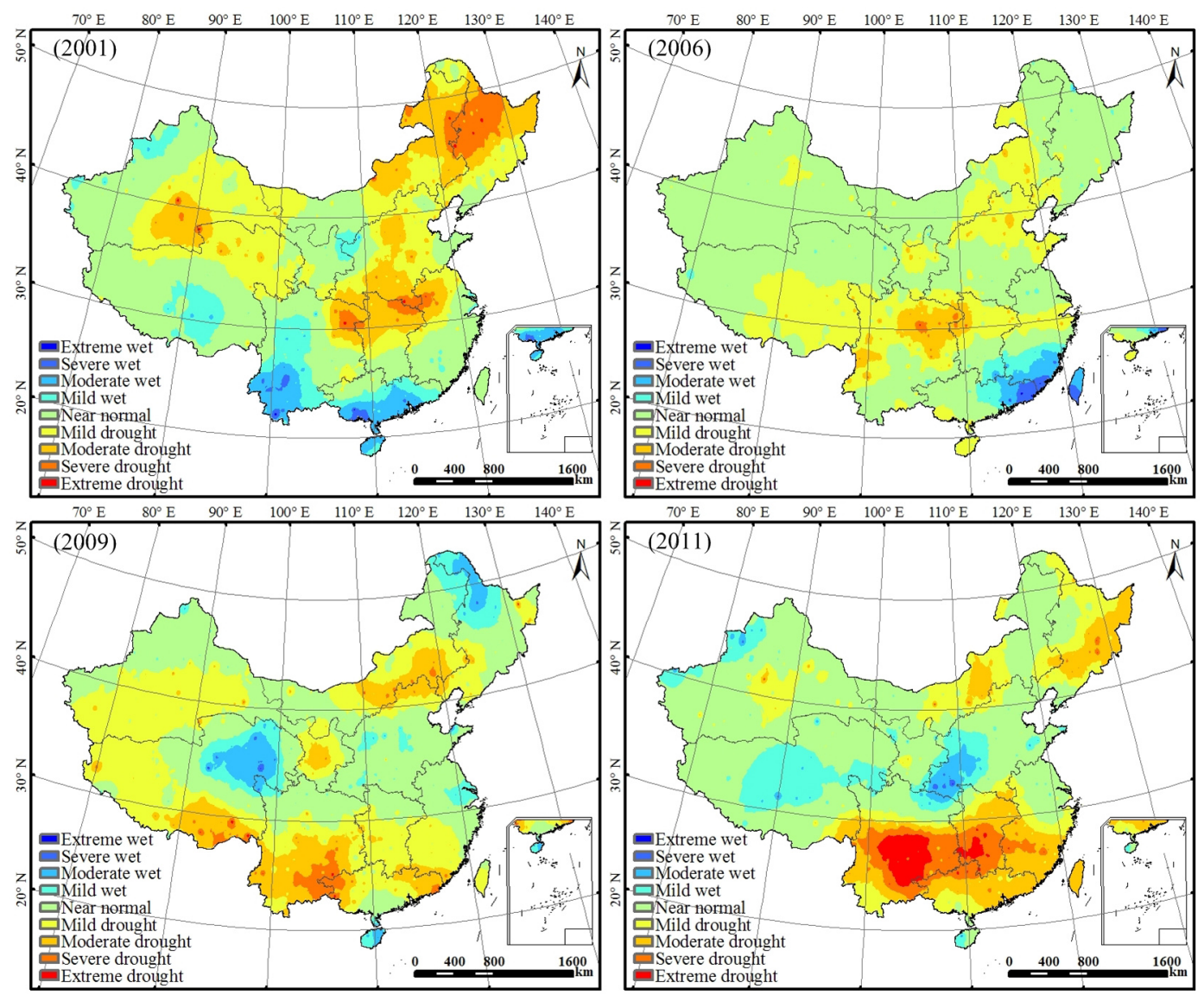

Fig. 4. Areas hit by different severities of droughts in 2001, 2006, 2009 and 2011.

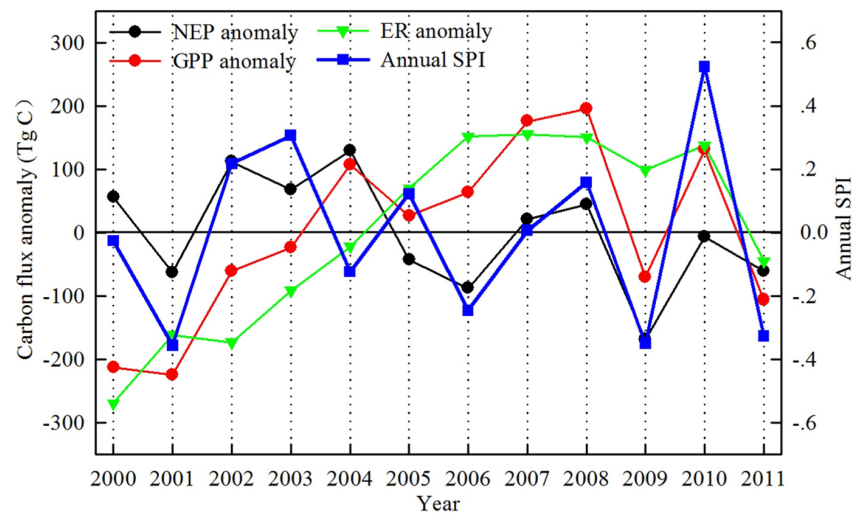

Fig. 5. Anomalies of annual national total NEP, GPP, and ER from multiyear means and annual mean SPI in China from 2000 to 2011. Annual SPI presented here is mean of the 12-month SPI through the end of December for all pixels over China.

notably decreasing national NEP. The largest decrease in national total annual NEP in the study period resulted from the drought of 2009, which decreased total national annual GPP and increased total national annual ER.

\subsubsection{Response of carbon sequestration to droughts in different regions}

In 2001, the decrease in simulated NEP mainly occurred in regions to the north of the Yangtze River (the blue and cyan colored areas in Fig. 6), including most of North China, the northern parts of Southeast and Central China, and the east of Northwest China (Fig. 6). In drought-affected regions, annual GPP and ER decreased with low availability of water. The reduction in GPP was larger than that in ER in most areas, resulting in decreases in NEP; these decreases were most significant in North and Northwest China. The SAI values of total NEP in these two regions were below -1.5 (Fig. 7).

The decrease in NEP in 2006 mainly occurred in the central areas of China (the blue and cyan colored areas in Fig. 6), such as the northern parts of Southwest and Central China, the northern and middle parts of Southeast China, and the eastern area of the Tibetan Plateau. The slight decrease in GPP and slight to large increase in ER were primarily responsible for the reduction in carbon sequestration in drought-affected areas. The SAI values of regional total NEP in Southwest and Central China were -1.25 and -1.26 , respectively (Figs. 6 and 7), indicating moderate reductions in total regional NEP here. 


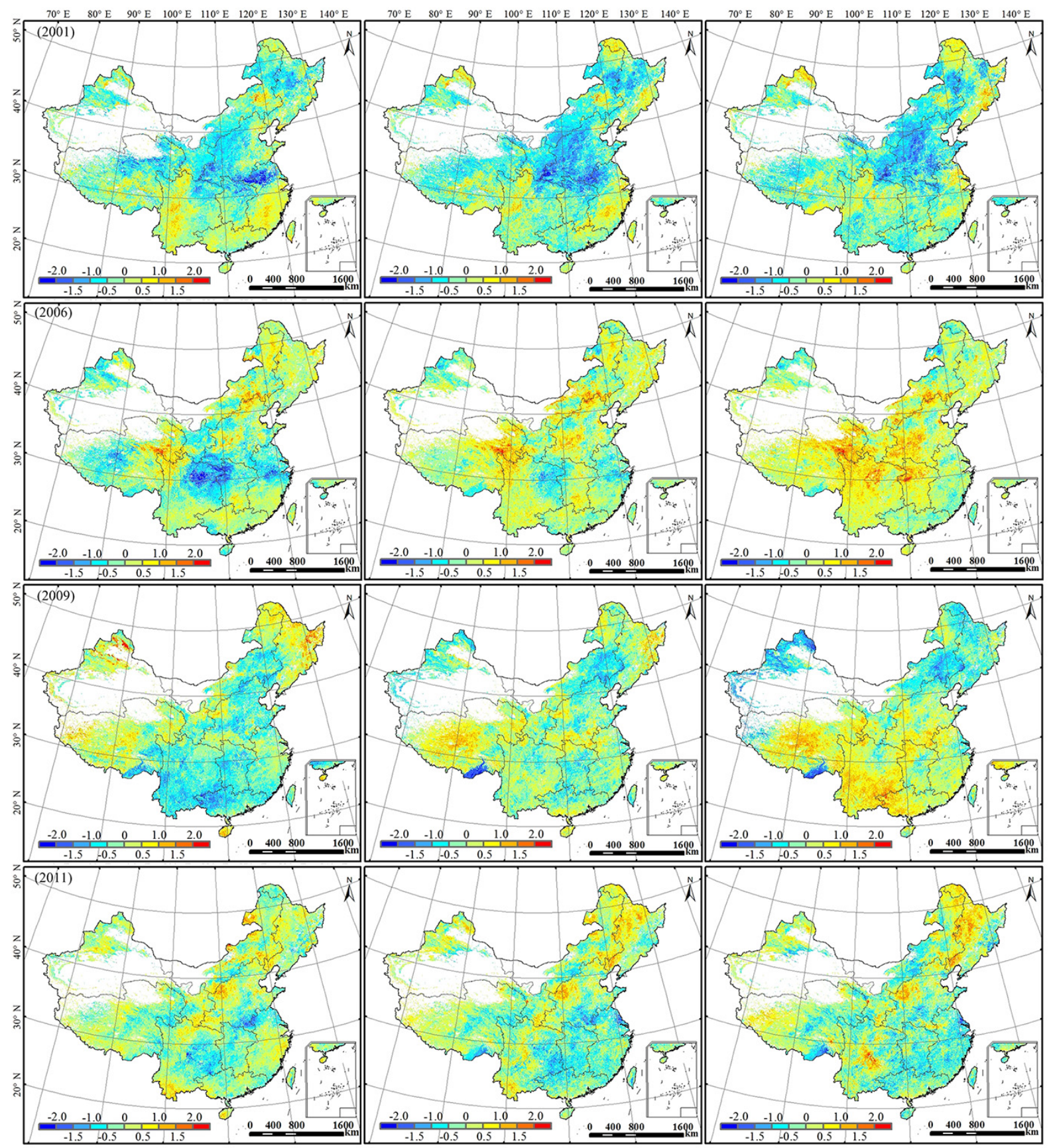

Fig. 6. The spatial distributions of SAI values of annual NEP (left panels), GPP (central panels), and ER (right panels) in 2001, 2006, 2009 and 2011, respectively. SAI values were calculated using Eq. (6). Negative values (the blue and cyan colored areas) represent annual GPP, $\mathrm{ER}$, and NEP smaller than 12-year means, and vice versa.

NEP decreased throughout the regions of China in 2009 with the exceptions of Northeast China, most of the Tibetan Plateau and the western part of Northwest China (Fig. 6). Moderate and severe droughts increased heterotrophic respiration. The slight to moderate decreases in GPP along with slight to large increases in ER caused the large decrease in NEP. Regional NEP totals decreased sharply in
South China $\left(\mathrm{NEP}_{\mathrm{SAI}}=-2.23\right)$, severely in the Tibetan Plateau $\left(\mathrm{NEP}_{\mathrm{SAI}}=-1.50\right)$ and Southwest China $\left(\mathrm{NEP}_{\mathrm{SAI}}=\right.$ $-1.80)$, and moderately in Central $\left(\mathrm{NEP}_{\mathrm{SAI}}=-1.42\right)$ and Southeast China ( NEP $\left._{\text {SAI }}=-1.08\right)$ (Fig. 7).

In 2011, moderate to extreme droughts hit regions south of the Yangtze River (Fig. 4), resulting in decreased GPP. Concurrently, the reduction in heterotrophic respiration caused 

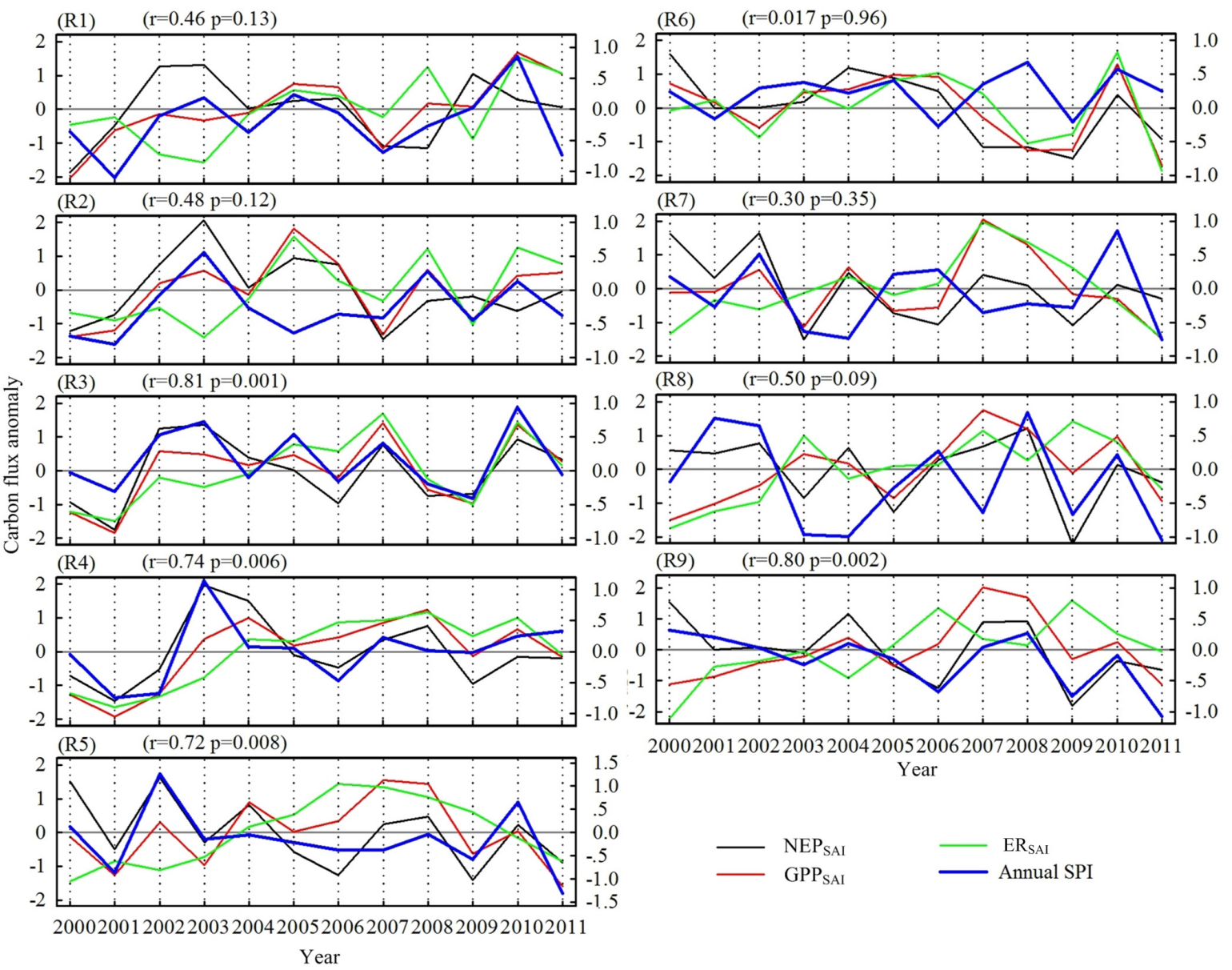

(R8) $\quad(\mathrm{r}=0.50 \mathrm{p}=0.09)$

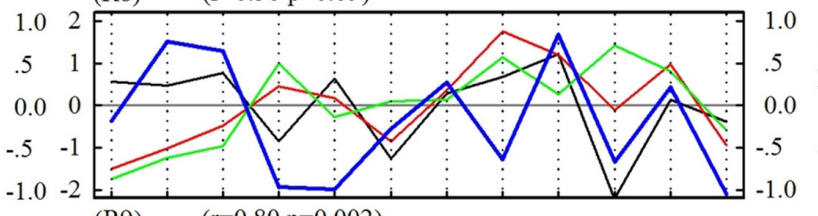

(R9) $\quad(\mathrm{r}=0.80 \mathrm{p}=0.002)$
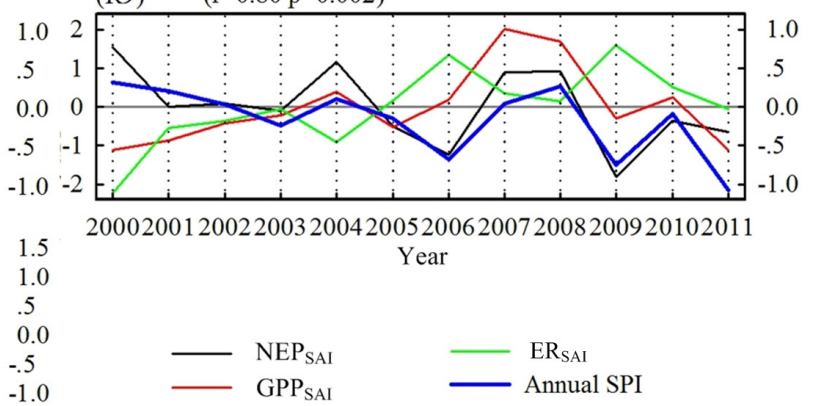

Fig. 7. Anomalies of annual total NEP, GPP and ER, along with annual mean SPI in nine regions of China from 2000 to 2011 . SPI presented here is the mean of 12-month SPI through the end of December for all pixels in a specific region of China. R1: Northeast China; R2: Inner Mongolia; R3: Northwest China; R4: North China; R5: Central China; R6: Tibetan Plateau; R7: Southeast China; R8: South China; R9: Southwest China.

by very low SWC led to a mild decrease in ER. As a consequence, the decrease in NEP was smaller in 2011 than in 2009. The decrease in NEP mainly occurred in Central China, the eastern part of Southwest China and adjacent areas of North and Southeast China (Fig. 6).

Figure 7 shows the anomalies of annual total GPP, ER, and NEP, along with annual mean SPI in different regions of China. The anomalies of annual total NEP were positively correlated with annual mean SPI at the 0.01 significance level in Northwest, North, Central, and Southwest China. However, the linkage of NEP anomalies with annual mean SPI was not significant in Northeast China, Inner Mongolia or the Tibetan Plateau, where temperature is also a key factor controlling carbon sequestration. It should be noted that most areas of Inner Mongolia are arid and semiarid, so vegetation activity is mainly controlled by water availability. However, in the northeastern part of Inner Mongolia, where the climate is sub-humid or semiarid, water availability does not act as the most crucial limiting factor of vegetation activity. Northeast- ern terrestrial ecosystems account for a large fraction of Inner Mongolia's total carbon sequestration capacity. Therefore, this region's total carbon sequestration capacity is not very sensitive to precipitation anomalies. In humid Southeast and South China, the total NEP anomaly is also not significantly correlated with annual mean SPI. In these regions, temperature and water availability are normally suitable for vegetation growth, while radiation dominantly drives the interannual variability of productivity (Nemani et al., 2003). Precipitation increase is normally associated with radiation decrease, possibly causing NEP decrease to some extent here. The decrease in annual NEP with the increase in annual precipitation was also recently reported by Yan et al. (2013) for a tropical old-growth forest and a subtropical old-growth forest in southern China on the basis of flux measurements for the period from 2003 to 2009.

The simulations here indicate that droughts in China during the past 12 years generally caused detectable reductions of GPP and NEP in areas strongly affected by the droughts 


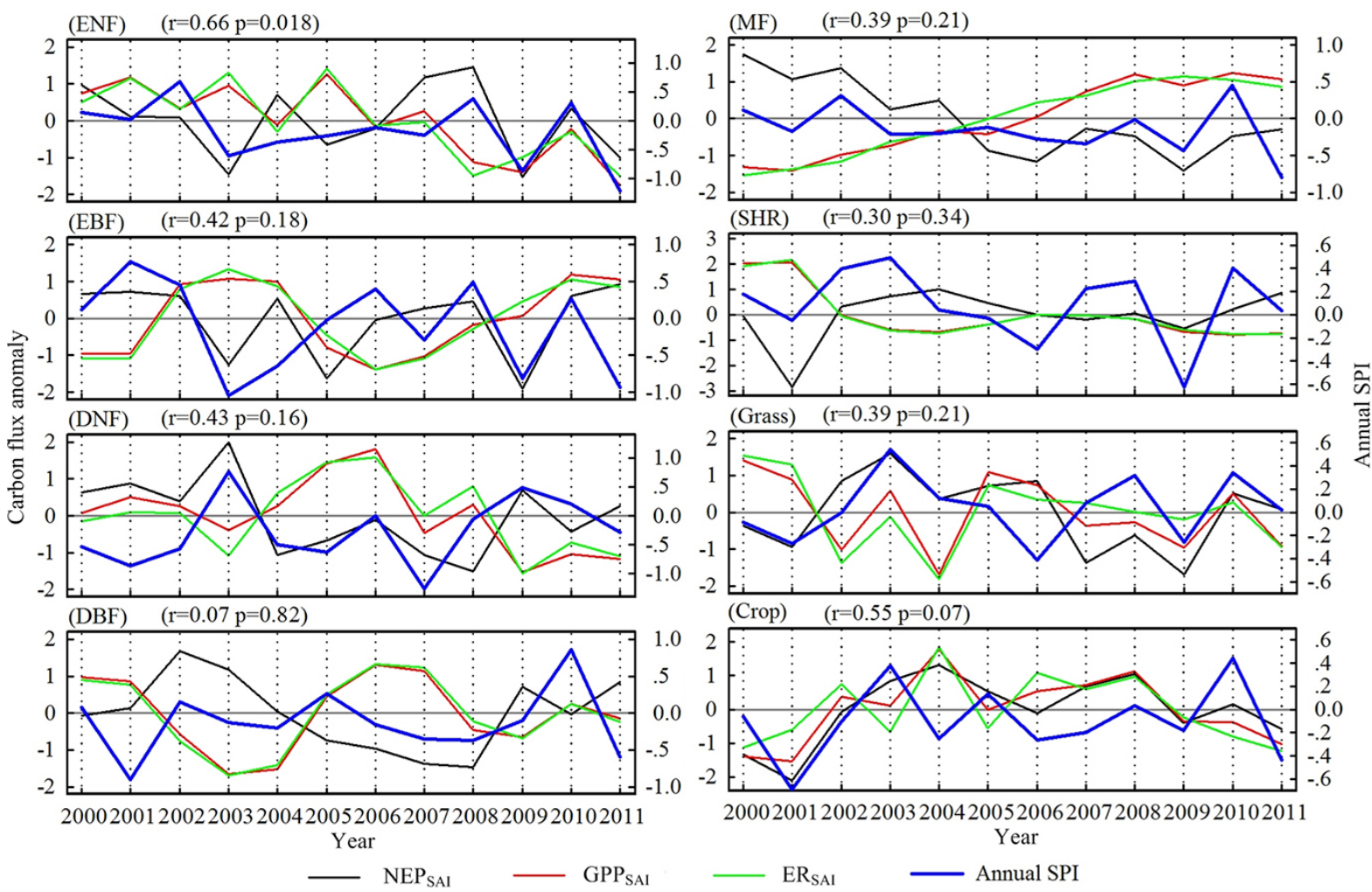

Fig. 8. Anomalies of annual NEP, GPP, and ER from multiyear means and annual mean SPI for different land cover types from 2000 to 2011. ENF: evergreen needleleaf forest; EBF: evergreen broadleaf forest; DNF: deciduous needleleaf forest; DBF: deciduous broadleaf forest; MF: mixed forest; SHR: shrubland; Grass: grassland; Crop: cropland and cropland/natural vegetation mosaic.

(Figs. 6 and 7). Similar negative effects of droughts on carbon sequestration were reported in previous studies conducted in Europe (Ciais et al., 2005; Vetter et al., 2008) and the United States (Xiao et al., 2011; Chen et al., 2012a; Schwalm et al., 2012).

\subsubsection{Drought sensitivity of carbon sequestration by different vegetation types}

The drought sensitivity of simulated carbon sequestration varied with land cover types (Fig. 8), which has been reported by previous studies based on flux measurements (Schwalm et al., 2010a; Pannatier et al., 2012; Thomas et al., 2013). Overall, evergreen needleleaf forest showed the highest correlation of annual mean NEP anomaly with annual mean SPI $(r=0.66, p=0.018)$, followed by cropland $(r=0.55$, $p=0.07)$. The annual carbon sequestration by deciduous broadleaf forest showed the lowest drought sensitivity. Other land cover types exhibited similar sensitivity. Because the same land cover types exist in different regions, it can be concluded that the drought sensitivity of carbon sequestration changed more based on regions than on land cover types.

Crops and grasslands, unable to use water in deeper soil layers because of their relatively short roots, are typically sensitive to droughts (Schwalm et al., 2010a; Wu and Chen,
2013). Droughts might decrease the carbon sequestration capacity of grassland (Dong et al., 2011; Yang and Zhou, 2013), or even change grassland from a carbon sink in "wet" years to a carbon source in "dry" ones (Aires et al., 2008; Jongen et al., 2011). The simulation here shows that the national total of carbon sequestration by grassland in China was negatively affected by drought severity, but not significantly. This is because a considerable fraction of grassland is located in the Tibetan Plateau, where carbon sequestration is very sensitive to droughts. Our simulation showed that total carbon sequestration by evergreen forests was more sensitive to droughts than that by deciduous forests, which is consistent with the findings by $\mathrm{Wu}$ and Chen. (2013) for the response of carbon sequestration to droughts by different types of forests in North America. Granier et al. (2007) pointed out that carbon sequestration by coniferous forests appeared to be less affected by droughts than that by broadleaved forests during the 2003 European heat wave; this contrasts with the relative sensitivity of carbon sequestration by coniferous and broadleaved forests identified here.

\subsection{The accumulative lagged effect of droughts on NEP}

Figure 9 shows the maximum correlation coefficient between SPI and monthly NEP $_{\text {SAI }}$ for the 2000-2011 period 

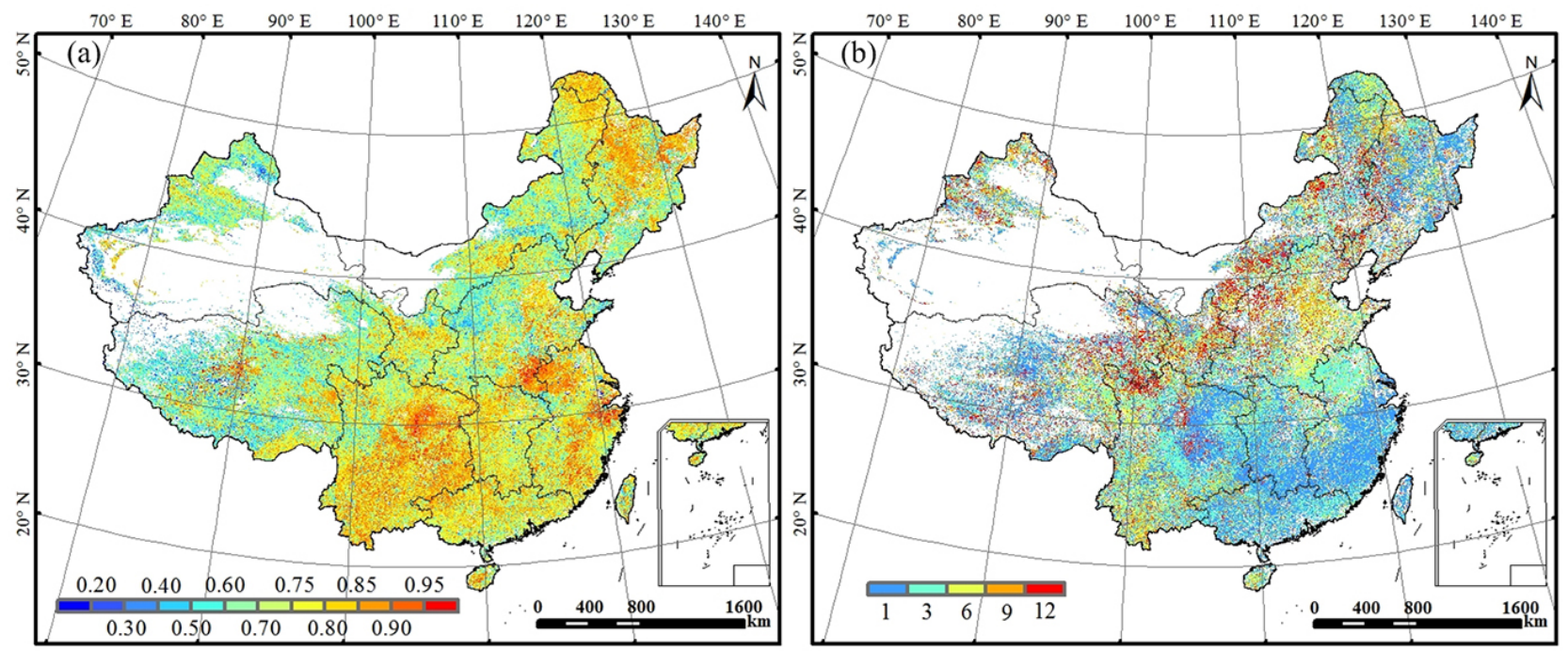

Fig. 9. (a) Spatial distribution of the correlations between SPI and annual NEPSAI for the period 2000-2011. The values represent the maximum correlation recorded for each pixel independently of the month of the year and the SPI timescale. (b) SPI timescales at which the maximum correlation between SPI and NEPSAI is found. Areas with no significant correlations $(p<0.05)$ are indicated in white. Desert and ice areas are masked and not included in the analyses.

and the SPI timescales at which the maximum correlation

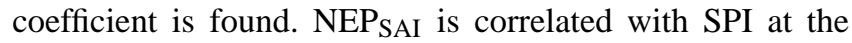
0.05 significance level over $82 \%$ of the vegetated land areas (Fig. 9a), especially in southwestern, southeastern and northeastern China. The SPI timescales corresponding to the

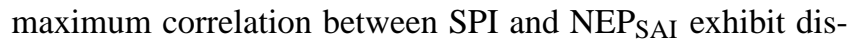
tinguishable spatial patterns (Fig. 9b). Droughts had relatively shorter timescales of accumulative lagged effect on NEP in the southern regions of China (e.g., 1-3 months). In cropland regions, NEP responded to droughts at middle timescales (about 6 months). Droughts might impact NEP at longer timescales in cold grassland areas than in other regions.

\section{Discussion}

\subsection{Drought impact on the national terrestrial carbon budget}

Although estimates are still inconsistent, many studies have indicated that China's terrestrial ecosystems have acted as carbon sinks in recent decades (Cao et al., 2003; Houghton and Hackler, 2003; Pan et al., 2004; Piao et al., 2009a; Fang et al., 2007; Tian et al., 2011b). Piao et al. (2009a) suggested that terrestrial carbon sinks amounted to $0.19-0.26 \mathrm{Pg} \mathrm{C} \mathrm{yr}^{-1}$ during the 1980s and 1990s, accounting for $28-37 \%$ of concurrent $\mathrm{CO}_{2}$ emissions in China. The quick increase in anthropogenic carbon emissions in China in recent years (Wang et al., 2012a) implies the increasing importance of terrestrial carbon sinks. Our simulation indicates that the national total NEP of China slightly declined during the period from
2000 to 2011 ( $\left.-11.3 \mathrm{Tg} \mathrm{C} \mathrm{yr}^{-1}\right)$, mainly due to considerable reductions in NEP caused by extensive, severe droughts in 2001, 2006, 2009, and 2011. In these four years, the de-

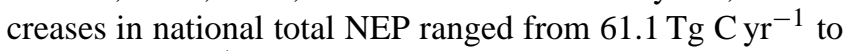
$168.8 \mathrm{Tg} \mathrm{Cyr}^{-1}$, approximately 30 to $94 \%$ of the average carbon sink strength of forests during the 1999-2008 period, estimated using forest inventory data (Pan et al., 2011; Guo et al., 2013; Zhang et al., 2013). Therefore, droughts negatively influence the terrestrial carbon sink in China. With possible increases in drought frequency and severity in future (IPCC, 2007; Dai, 2013), the role of China's terrestrial ecosystems in offsetting fossil fuel emission might be further weakened.

Changes in GPP and ER play differing though dominant roles in changing NEP in the four studied drought years. GPP and ER are two major components of NEP. The effect of droughts on annual NEP depends on the relative responses of annual GPP and annual ER to drought. The response of $R_{\mathrm{h}}$, the major component of ER, to SWC is inversely parabolic. Therefore, based on SWC, droughts might increase or decrease ER. In addition, GPP is mainly affected by droughts in growing seasons, while ER might be affected by droughts throughout all seasons. Vegetation can optimize the uptake of soil water from different soil layers. At the initiation stage of drought, GPP is impacted only marginally, thanks to the absorption of water from deep soil layers by vegetation, which maintains a normal photosynthesis rate. At the same time, ER might be significantly affected since soil organic carbon is usually concentrated in upper soil layers. Therefore, the response to droughts of annual NEP along with GPP and ER might change spatially and temporally with the severity, continuation and timing of droughts. 


\subsection{Lagged effect of droughts on carbon sequestration by terrestrial ecosystems}

It was found here that droughts have lagged effects on NEP. The timescales at which NEP most significantly responds to droughts differ spatially; they are short in the eastern regions, which are warm and humid, and long in the northern and western regions, which are composed of cold, semiarid grassland. Similar findings have been reported in studies that used the greenness index, chronologies of ring width, and NPP as vegetation growth indicators for assessing the influence of droughts on vegetation. The lag time of drought effects on growth indicators is related to vegetation types and local conditions. Ji and Peters (2003) found out that the 3month SPI was most strongly correlated with the growingseason NDVI in the US Great Plains. Based on the analysis of NDVI-SPI co-variability over different temporal scales, Lotsch et al. (2003) suggested that 5-month SPI be used to assess the response of terrestrial ecosystems to droughts. Jain et al. (2010) showed that the NDVI has the highest correlation with 1-month, 3-month, and 9-month SPI in different regions of India. In the US state of Texas, the growingseason vegetation condition index (NDVI-based) was found to be most strongly correlated with the 6-month and 9-month SPI (Quiring and Ganesh, 2010). The correlation between chronologies of ring width and different timescales of SPI for eight tree species in northeastern Spain indicated that the tree growth most significantly responded to 9-11 months SPI for xeric sites and to shorter than 5-month SPI for mesic sites, respectively (Pasho et al., 2011). Recent studies found that correlations between drought intensity and NPP anomalies in China were strongest during or after the peak of a drought (Chen et al., 2013; Pei et al., 2013). With vegetation indices from satellite imagery, tree-ring growth series, and aboveground net primary production records, Vicente-Serrano et al. (2013) recently reported the responses of global biomes to droughts. They found that both arid and humid biomes respond to droughts at short timescales, while semiarid and sub-humid biomes respond to droughts at long timescales. This is similar to our findings in this study. Based on in situ eddy covariance flux and meteorological observation data taken from the Qianyanzhou station in southern China, Huang et al. (2013) found that droughts exerted an approximate one-month negative lagged effect on potential productivity.

NEP is the balance between GPP and ER. Accordingly, the responses of GPP and ER to droughts determine the response of NEP. When surface soil dries during the initiation stage of a drought, deep soil might be still wet, allowing plants to take in water and thereby maintain normal stomata functional and carbon assimilation. Meanwhile, heterotrophic respiration is limited by the decreased availability of water in surface soil. Consequently, NEP would not decrease or even increase. With the continuation of a drought, water in deep soil layers will diminish and large decreases of GPP will occur, result- ing in a reduction in NEP (Ju et al., 2006; Barr et al., 2007). These phenomena have been confirmed by eddy covariance measurements (Granier et al., 2007; Kljun et al., 2007). Krishnan et al. (2006) reported that after experiencing a threeyear drought, a boreal aspen stand in central Saskatchewan, Canada, continued a decline in both growth and LAI two years after the drought. Pereira et al. (2007) demonstrated that the GPP, ER, and NEP of a eucalyptus plantation located in southern Portugal decreased during the drought years, the largest absolute decrease occurring in the second year.

\subsection{Uncertainties and remaining issues}

In this study, the response to droughts of terrestrial carbon sequestration in China was explored with the BEPS model, which was driven by spatially distributed remote sensing data (LAI, land cover) as well as meteorological and soil texture data. There may still be some uncertainties. For example, the explicit dynamics of soil water content is pivotal to understanding the impact of drought on carbon sequestration by terrestrial ecosystems (Reichstein et al., 2002; Samanta et al., 2011). Like most ecological models, the BEPS model used here does not account for the horizontal movement of soil water. This simplification would overestimate or underestimate the impact of droughts on carbon sequestration in low and upper slope areas. Irrigation, popularly practiced for most croplands in China, was not included in the BEPS model. Consequently, the negative effects of droughts on carbon sequestration by croplands might be overestimated.

The LAI is a key input to the BEPS model. In this study, the LAI was inverted using the MODIS reflectance data. Although the advantages of this LAI inversion algorithm have been proven in a series of previous studies, the quality of the LAI depends largely on the quality of MODIS reflectance data, which is not guaranteed in many areas of China, especially in summer. A locally adjusted cubic-spline capping (LACC) method (Chen et al., 2006) was employed here to remove unrealistic fluctuations of LAI caused by residual cloud contamination and atmospheric noise. However, it is impossible to remove noise using the LACC method if high-quality MODIS data are not available for a lengthy period. The uncertainty in LAI would extend into estimated NEP.

In this study, the site-observed precipitation data was interpolated into spatial grid data using the IDW method. Spatial variability and the density of observations largely determine the accuracy of precipitation interpolated in this way. In summer, precipitation often shows significant spatial variability, especially in complex terrains. In addition, no meteorological data was available in the Taiwan province, and precipitation observations were sparse in northwestern China. These limitations inevitably lead to some uncertainties in interpolated precipitation data, and consequently in simulated sensitivity of carbon sequestration to droughts. In this study, only 1-, 3-, 6-, 9-, and 12-month SPIs were selected for assessing the effect of droughts on carbon sequestration. This simplification 
might fail to identify the exact timescale at which droughts have the strongest lagged effect on carbon sequestration.

NEP is affected by a number of factors, such as climate, disturbances, and land cover change. Here, only the influence of extensive, severe droughts on terrestrial NEP in China was investigated. Droughts might invoke other disturbances, such as fire, disease, insects, mortality or re-growth (Allen et al., 2010; Peng et al., 2011; van der Molen et al., 2011; Ma et al., 2012). Such indirect effects on terrestrial carbon sequestration were not explored here. Changes in land cover and land use could also significantly modify the terrestrial carbon cycle (Piao et al., 2007; Xiao et al., 2009). During the study period, dramatic urbanization (Wang et al., 2012b) and large-scale forest plantation programs have concurrently occurred in China (Piao et al., 2012), consequently impacting terrestrial carbon cycles at regional and national scales. The application of remotely sensed LAI here can only partially represent the effects of land cover change and indirect effects on carbon sequestration. For more accurate assessment of drought effects on terrestrial carbon sequestration, these effects should be carefully considered in future research.

\section{Conclusions}

In this study, the influences of droughts on carbon sequestration by terrestrial ecosystems during the period from 2000 to 2011 were assessed by model simulation and remote sensing data. The main conclusions are:

1. Droughts, as indicated by the SPI, occurred extensively and frequently in China during the period from 2000 to 2011, especially in 2001, 2006, 2009, and 2011. The spatial patterns of the droughts differed in these four years.

2. The national total NEP declined by $-11.3{\mathrm{Tg} \mathrm{C} \mathrm{yr}^{-2}}^{-2}$ during the period from 2000 to 2011 , mainly due to the large reductions in NEP in 2001, 2006, 2009, and 2011. Anomalies of national total NEP were correlated with annual SPI $(r=0.54, p=0.06)$. The regional totals of annual NEP, while sensitive to precipitation anomalies in Northwest, North, Central, and Southwest China, were not sensitive to precipitation anomalies in other regions.

3. The drivers of national total NEP reductions differed during the study years. In 2001 and 2011, droughts caused national totals of both GPP and ER to decrease. The former decreased to a large degree, resulting in decreases in national total NEP. In 2006, droughts were mostly mild or moderate, and the decrease in NEP was caused by a smaller increase in GPP compared with ER. In 2009, the largest decreases in national total NEP during the study period were caused by the decrease in GPP and the increase in ER.
4. Droughts have accumulative lagged effects on carbon sequestration. The speed and degree at which NEP responds to droughts vary spatially, rapidly and significantly in the eastern regions of China, which are humid and warm. In contrast, NEP responds to droughts relatively slowly and less significantly in the northern and western regions, which are cold and arid.

Acknowledgements. This study is funded by the National Basic Research Program of China (973 Program) (2010CB950702 and 2010CB833503), Special climate change fund (CCSF201312), the Priority Academic Program Development of Jiangsu Higher Education Institutions, and the National Natural Science Foundation of China (41271354 and 41375160). We would greatly like to thank Professor Scott Munro, University of Toronto for editing this manuscript. We gratefully acknowledge the constructive suggestions by anonymous reviewers for their constructive comments, which helped to improve the quality of the manuscript greatly.

Edited by: J. Xiao

\section{References}

Aires, L. M., Pio, C. A., and Pereira, J. S.: The effect of drought on energy and water vapour exchange above a mediterranean $\mathrm{C} 3 / \mathrm{C} 4$ grassland in Southern Portugal, Agr. Forest Meteorol., 148, 565579, 2008.

Allen, C. D., Macalady, A. K., Chenchouni, H., Bachelet, D., McDowell, N., Vennetier, M., Kitzberger, T., Rigling, A., Breshears, D. D., Hogg, E. H., Gonzalez, P., Fensham, R., Zhang, Z., Castro, J., Demidova, N., Lim, J. H., Allard, G., Running, S. W., Semerci, A., and Cobb, N.: A global overview of drought and heatinduced tree mortality reveals emerging climate change risks for forests, For. Ecol. Manage., 259, 660-684, 2010.

Arnone, J. A., III, Verburg, P. S. J., Johnson, D. W., Larsen, J. D., Jasoni, R. L., Lucchesi, A. J., Batts, C. M., von Nagy, C., Coulombe, W. G., Schorran, D. E., Buck, P. E., Braswell, B. H., Coleman, J. S., Sherry, R. A., Wallace, L. L., Luo, Y., and Schimel, D. S.: Prolonged suppression of ecosystem carbon dioxide uptake after an anomalously warm year, Nature, 455, 383-386, 2008.

Baldocchi, D.: Environmental science: The carbon cycle under stress, Nature, 437, 483-484, 2005.

Barr, A. G., Black, T. A., Hogg, E. H., Kljun, N., Morgenstern, K., and Nesic, Z.: Inter-annual variability in the leaf area index of a boreal aspen-hazelnut forest in relation to net ecosystem production, Agr. Forest Meteorol., 126, 237-255, 2004.

Barr, A. G., Black, T. A., Hogg, E. H., Griffis, T. J., Morgenstern, K., Kljun, N., Theede, A., and Nesic, Z.: Climatic controls on the carbon and water balances of a boreal aspen forest, 1994-2003, Glob. Change Biol., 13, 561-576, 2007.

Barriopedro, D., Gouveia, C. M., Trigo, R. M., and Wang, L.: The 2009/10 drought in China: possible causes and impacts on vegetation, J. Hydrometeorol., 13, 1251-1267, 2012.

Cao, M. K., Prince, S. D., Li, K. R., Tao, B., Small, J., and Shao, X. M.: Response of terrestrial carbon uptake to climate interannual variability in China, Glob. Change Biol., 9, 536-546, 2003. 
Chen, G., Tian, H., Zhang, C., Liu, M., Ren, W., Zhu, W., Chappelka, A. H., Prior, S. A., and Lockaby, G. B.: Drought in the Southern United States over the 20th century: variability and its impacts on terrestrial ecosystem productivity and carbon storage, Clim. Change, 114, 379-397, 2012a.

Chen, J. M., Liu, J., Cihlar, J., and Goulden, M. L.: Daily canopy photosynthesis model through temporal and spatial scaling for remote sensing applications, Ecol. Model., 124, 99-119, 1999.

Chen, J. M., Chen, X. Y., Ju, W. M., and Geng, X. Y.: Distributed hydrological model for mapping evapotranspiration using remote sensing inputs, J. Hydrol., 305, 15-39, 2005.

Chen, J. M., Deng, F., and Chen, M. Z.: Locally adjusted cubicspline capping for reconstructing seasonal trajectories of a satellite-derived surface parameter, IEEE Trans. Geosci. Remote Sensing, 44, 2230-2238, 2006.

Chen, J. M., Mo, G., Pisek, J., Liu, J., Deng, F., Ishizawa, M., and Chan, D.: Effects of foliage clumping on the estimation of global terrestrial gross primary productivity, Global Biogeochem. Cy., 26, GB1019, doi:10.1029/2010gb003996, 2012b.

Chen, T., Werf, G. R., Jeu, R. A. M., Wang, G., and Dolman, A. J.: A global analysis of the impact of drought on net primary productivity, Hydrol. Earth Syst. Sc., 17, 3885-3894, 2013.

Ciais, P., Reichstein, M., Viovy, N., Granier, A., Ogee, J., Allard, V., Aubinet, M., Buchmann, N., Bernhofer, C., Carrara, A., Chevallier, F., De Noblet, N., Friend, A. D., Friedlingstein, P., Grunwald, T., Heinesch, B., Keronen, P., Knohl, A., Krinner, G., Loustau, D., Manca, G., Matteucci, G., Miglietta, F., Ourcival, J. M., Papale, D., Pilegaard, K., Rambal, S., Seufert, G., Soussana, J. F., Sanz, M. J., Schulze, E. D., Vesala, T., and Valentini, R.: Europewide reduction in primary productivity caused by the heat and drought in 2003, Nature, 437, 529-533, 2005.

Cox, P. M., Betts, R. A., Jones, C. D., Spall, S. A., and Totterdell, I. J.: Acceleration of global warming due to carbon-cycle feedbacks in a coupled climate model, Nature, 408, 184-187, 2000.

Dai, A.: Increasing drought under global warming in observations and models, Nature Clim. Change, 3, 52-58, 2013.

Dai, A. G.: Drought under global warming: a review, Wires. Clim. Change, 2, 45-65, 2011.

Deng, F., Chen, J. M., Plummer, S., Chen, M. Z., and Pisek, J.: Algorithm for global leaf area index retrieval using satellite imagery, IEEE Trans. Geosci. Remote Sens., 44, 2219-2229, 2006.

Dong, G., Guo, J. X., Chen, J. Q., Sun, G., Gao, S., Hu, L. J., and Wang, Y. L.: Effects of spring drought on carbon sequestration, evapotranspiration and water use efficiency in the Songnen meadow steppe in Northeast China, Ecohydrology, 4, 211-224, 2011

Fang, J. Y., Guo, Z. D., Piao, S. L., and Chen, A. P.: Terrestrial vegetation carbon sinks in China, 1981-2000, Sci. China Ser. D., 50, 1341-1350, 2007.

Farquhar, G. D., Caemmerer, S. V., and Berry, J. A.: A biochemicalmodel of photosynthetic $\mathrm{CO}_{2}$ assimilation in leaves of $\mathrm{C}_{3}$ species, Planta, 149, 78-90, 1980.

Feng, X., Liu, G., Chen, J. M., Chen, M., Liu, J., Ju, W. M., Sun, R., and Zhou, W.: Net primary productivity of China's terrestrial ecosystems from a process model driven by remote sensing, J. Environ. Manage., 85, 563-573, 2007.

Friedl, M. A., Sulla-Menashe, D., Tan, B., Schneider, A., Ramankutty, N., Sibley, A., and Huang, X.: MODIS Collection 5 global land cover: Algorithm refinements and characterization of new datasets, Remote Sens. Environ., 114, 168-182, 2010.

Gao, H. and Yang, S.: A severe drought event in northern China in winter 2008-2009 and the possible influences of La Nina and Tibetan Plateau, J. Geophys. Res.-Atmos., 114, D24104, doi:10.1029/2009JD012430, 2009.

Garrigues, S., Lacaze, R., Baret, F., Morisette, J. T., Weiss, M., Nickeson, J. E., Fernandes, R., Plummer, S., Shabanov, N. V., Myneni, R. B., Knyazikhin, Y., and Yang, W.: Validation and intercomparison of global Leaf Area Index products derived from remote sensing data, J. Geophys. Res.-Biogeosci., 113, 20, G02028, doi:10.1029/2007jg000635, 2008.

Granier, A., Reichstein, M., Breda, N., Janssens, I. A., Falge, E., Ciais, P., Grunwald, T., Aubinet, M., Berbigier, P., Bernhofer, C., Buchmann, N., Facini, O., Grassi, G., Heinesch, B., Ilvesniemi, H., Keronen, P., Knohl, A., Kostner, B., Lagergren, F., Lindroth, A., Longdoz, B., Loustau, D., Mateus, J., Montagnani, L., Nys, C., Moors, E., Papale, D., Peiffer, M., Pilegaard, K., Pita, G., Pumpanen, J., Rambal, S., Rebmann, C., Rodrigues, A., Seufert, G., Tenhunen, J., Vesala, I., and Wang, Q.: Evidence for soil water control on carbon and water dynamics in European forests during the extremely dry year: 2003, Agr. Forest Meteorol., 143, 123-145, 2007.

Guo, Z. D., Hu, H. F., Li, P., Li, N. Y., and Fang, J. Y.: Spatiotemporal changes in biomass carbon sinks in China's forests from 1977-2008, Sci. China Life Sci., 56, 661-671, 2013.

Hayes, M. J., Svoboda, M. D., Wilhite, D. A., and Vanyarkho, O. V.: Monitoring the 1996 drought using the standardized precipitation index, Bull. Am. Meteorol. Soc., 80, 429-438, 1999.

He, B., Lu, A. F., Wu, J. J., Zhao, L., and Liu, M.: Drought hazard assessment and spatial characteristics analysis in China, J. Geogr. Sci., 21, 235-249, 2011.

Houghton, R. A. and Hackler, J. L.: Sources and sinks of carbon from land-use change in China, Global Biogeochem. Cy., 17, 1034, doi:10.1029/2002gb001970, 2003.

Hu, Z., Yu, G., Fan, J., Zhong, H., Wang, S., and Li, S.: Precipitation-use efficiency along a $4500-\mathrm{km}$ grassland transect, Glob. Ecol. Biogeogr., 19, 842-851, 2010.

Huang, K., Wang, S., Zhou, L., Wang, H., Liu, Y., and Yang, F.: Effects of drought and ice rain on potential productivity of a subtropical coniferous plantation from 2003 to 2010 based on eddy covariance flux observation, Environ. Res. Lett., 8, 035021, doi:10.1088/1748-9326/8/3/035021, 2013.

IPCC: Climate Change 2007: The Physical Science Basis: Working Group I Contribution to the Fourth Assessment Report of the IPCC, edited by: Solomon, S., Qin, D., Manning, M., Chen, Z., Marquis, M., Averyt, K. B., Tignor, M., and Miller, H. L., Cambridge University Press, 2007.

Jain, S. K., Keshri, R., Goswami, A., and Sarkar, A.: Application of meteorological and vegetation indices for evaluation of drought impact: a case study for Rajasthan, India, Nat. Hazards, 54, 643656, 2010.

Jarvis, P. G.: The interpretation of variations in leaf water potential and stomatal conductance found in canopies in field, Philos. T. Roy. Soc. B, 273, 593-610, 1976.

Ji, L. and Peters, A. J.: Assessing vegetation response to drought in the northern Great Plains using vegetation and drought indices, Remote Sens. Environ., 87, 85-98, 2003. 
Jongen, M., Pereira, J. S., Igreja Aires, L. M., and Pio, C. A.: The effects of drought and timing of precipitation on the inter-annual variation in ecosystem-atmosphere exchange in a Mediterranean grassland, Agr. Forest Meteorol., 151, 595-606, 2011.

Ju, W. M., Chen, J. M., Black, T. A., Barr, A. G., Liu, J., and Chen, B. Z.: Modelling multi-year coupled carbon and water fluxes in a boreal aspen forest, Agr. Forest Meteorol., 140, 136-151, 2006.

Ju, W. M., Gao, P., Zhou, Y. L., Chen, J. M., Chen, S., and Li, X. F.: Prediction of summer grain crop yield with a process-based ecosystem model and remote sensing data for the northern area of the Jiangsu Province, China, Internat. J. Remote Sens., 31, 1573-1587, 2010a.

Ju, W. M., Gao, P., Wang, J., Zhou, Y. L., and Zhang, X. H.: Combining an ecological model with remote sensing and GIS techniques to monitor soil water content of croplands with a monsoon climate, Agr. Water Manage., 97, 1221-1231, 2010 b.

Kljun, N., Black, T. A., Griffis, T. J., Barr, A. G., Gaumont-Guay, D., Morgenstern, K., McCaughey, J. H., and Nesic, Z.: Response of net ecosystem productivity of three boreal forest stands to drought, Ecosystems, 10, 1039-1055, 2007.

Krishnan, P., Black, T. A., Grant, N. J., Barr, A. G., Hogg, E. T. H., Jassal, R. S., and Morgenstern, K.: Impact of changing soil moisture distribution on net ecosystem productivity of a boreal aspen forest during and following drought, Agr. Forest Meteorol., 139, 208-223, 2006.

Law, B. E., Falge, E., Gu, L., Baldocchi, D. D., Bakwin, P., Berbigier, P., Davis, K., Dolman, A. J., Falk, M., Fuentes, J. D., Goldstein, A., Granier, A., Grelle, A., Hollinger, D., Janssens, I. A., Jarvis, P., Jensen, N. O., Katul, G., Mahli, Y., Matteucci, G., Meyers, T., Monson, R., Munger, W., Oechel, W., Olson, R., Pilegaard, K., Paw, K. T., Thorgeirsson, H., Valentini, R., Verma, S., Vesala, T., Wilson, K., and Wofsy, S.: Environmental controls over carbon dioxide and water vapor exchange of terrestrial vegetation, Agr. Forest Meteorol., 113, 97-120, 2002.

Liu, J., Chen, J. M., Cihlar, J., and Park, W. M.: A process-based boreal ecosystem productivity simulator using remote sensing inputs, Remote Sens. Environ., 62, 158-175, 1997.

Liu, J., Chen, J. M., Cihlar, J., and Chen, W.: Net primary productivity distribution in the BOREAS region from a process model using satellite and surface data, J. Geophys. Res.-Atmos., 104, 27735-27754, 1999.

Liu, J., Chen, J. M., and Cihlar, J.: Mapping evapotranspiration based on remote sensing: An application to Canada's landmass, Water Resour. Res., 39, 1189, doi:10.1029/2002WR001680, 2003.

Liu, Y., Ju, W., Chen, J., Zhu, G., Xing, B., Zhu, J., and He, M.: Spatial and temporal variations of forest LAI in China during 2000-2010, Chinese Sci. Bull., 57, 2846-2856, 2012.

Liu, Y., Ju, W., He, H., Wang, S., Sun, R., and Zhang, Y.: Changes of net primary productivity in China during recent 11 years detected using an ecological model driven by MODIS data, Front. Earth Sci., 7, 112-127, 2013a.

Liu, Y., Zhou, Y., Ju, W., Chen, J., Wang, S., He, H., Wang, H., Guan, D., Zhao, F., Li, Y., and Hao, Y.: Evapotranspiration and water yield over China's landmass from 2000 to 2010, Hydrol. Earth Syst. Sc., 17, 4957-4980, 2013b.

Lotsch, A., Friedl, M. A., Anderson, B. T., and Tucker, C. J.: Coupled vegetation-precipitation variability observed from satellite and climate records, Geophys. Res. Lett., 30, 1774, doi:10.1029/2003g1017506, 2003.

Lotsch, A., Friedl, M. A., Anderson, B. T., and Tucker, C. J.: Response of terrestrial ecosystems to recent Northern Hemispheric drought, Geophys. Res. Lett., 32, L06705, doi:10.1029/2004g1022043, 2005.

Lu, E., Luo, Y., Zhang, R., Wu, Q., and Liu, L.: Regional atmospheric anomalies responsible for the 2009-2010 severe drought in China, J. Geophys. Res.-Atmos., 116, D21114, doi:10.1029/2011jd015706, 2011.

Ma, Z., Peng, C., Zhu, Q., Chen, H., Yu, G., Li, W., Zhou, X., Wang, W., and Zhang, W.: Regional drought-induced reduction in the biomass carbon sink of Canada's boreal forests, Proc. Natl. Acad. Sci. USA, 109, 2423-2427, 2012.

Matsushita, B. and Tamura, M.: Integrating remotely sensed data with an ecosystem model to estimate net primary productivity in East Asia, Remote Sens. Environ., 81, 58-66, 2002.

McKee, T. B., Doesken, N. J., and Kleist, J.: The relationship of drought frequency and duration to time scales, 8th Conference on Applied Climatology, 179-184, 1993.

Meir, P., Metcalfe, D. B., Costa, A. C. L., and Fisher, R. A.: The fate of assimilated carbon during drought: impacts on respiration in Amazon rainforests, Philos. T. Roy. Soc. B, 363, 1849-1855, 2008.

Mishra, A. K. and Singh, V. P.: A review of drought concepts, J. Hydrol., 391, 204-216, 2010.

Mo, X. G., Chen, J. M., Ju, W. M., and Black, T. A.: Optimization of ecosystem model parameters through assimilating eddy covariance flux data with an ensemble Kalman filter, Ecol. Model., 217, 157-173, 2008.

Mu, Q., Zhao, M., Running, S. W., Liu, M., and Tian, H.: Contribution of increasing $\mathrm{CO}_{2}$ and climate change to the carbon cycle in China's ecosystems, J. Geophys. Res.-Biogeosci., 113, G01018, doi:10.1029/2006jg000316, 2008.

Nemani, R. R., Keeling, C. D., Hashimoto, H., Jolly, W. M., Piper, S. C., Tucker, C. J., Myneni, R. B., and Running, S. W.: Climatedriven increases in global terrestrial net primary production from 1982 to 1999, Science, 300, 1560-1563, 2003.

Nunes, E. L., Costa, M. H., Malhado, A. C. M., Dias, L. C. P., Vieira, S. A., Pinto, L. B., and Ladle, R. J.: Monitoring carbon assimilation in South America's tropical forests: Model specification and application to the Amazonian droughts of 2005 and 2010, Remote Sens. Environ., 117, 449-463, 2012.

Pan, Y. D., Luo, T. X., Birdsey, R., Hom, J., and Melillo, J.: New estimates of carbon storage and sequestration in China's forests: Effects of age-class and method on inventory-based carbon estimation, Clim. Change, 67, 211-236, 2004.

Pan, Y. D., Birdsey, R. A., Fang, J. Y., Houghton, R., Kauppi, P. E., Kurz, W. A., Phillips, O. L., Shvidenko, A., Lewis, S. L., Canadell, J. G., Ciais, P., Jackson, R. B., Pacala, S. W., McGuire, A. D., Piao, S. L., Rautiainen, A., Sitch, S., and Hayes, D.: A large and persistent carbon sink in the world's forests, Science, 333, 988-993, 2011.

Pannatier, E. G., Dobbertin, M., Heim, A., Schmitt, M., Thimonier, A., Waldner, P., and Frey, B.: Response of carbon fluxes to the 2003 heat wave and drought in three mature forests in Switzerland, Biogeochemistry, 107, 295-317, 2012.

Parton, W. J., Scurlock, J. M. O., Ojima, D. S., Gilmanov, T. G., Scholes, R. J., Schimel, D. S., Kirchner, T., Menaut, J. C., Seastedt, 
T., Moya, E. G., Kamnalrut, A., and Kinyamario, J. I.: Observations and Modeling of Biomass and Soil Organic-Matter Dynamics for the Grassland Biome Worldwide, Global Biogeochem. Cy., 7, 785-809, 1993.

Pasho, E., Julio Camarero, J., de Luis, M., and Vicente-Serrano, S. M.: Impacts of drought at different time scales on forest growth across a wide climatic gradient in north-eastern Spain, Agr. Forest Meteorol., 151, 1800-1811, 2011.

Pei, F., Li, X., Liu, X., and Lao, C.: Assessing the impacts of droughts on net primary productivity in China, J. Environ. Manage., 114, 362-371, 2013.

Peng, C., Ma, Z., Lei, X., Zhu, Q., Chen, H., Wang, W., Liu, S., Li, W., Fang, X., and Zhou, X.: A drought-induced pervasive increase in tree mortality across Canada's boreal forests, Nat. Clim. Change, 1, 467-471, 2011.

Pereira, J. S., Mateus, J. A., Aires, L. M., Pita, G., Pio, C., David, J. S., Andrade, V., Banza, J., David, T. S., Paço, T. A., and Rodrigues, A.: Net ecosystem carbon exchange in three contrasting Mediterranean ecosystems - the effect of drought, Biogeosciences, 4, 791-802, doi:10.5194/bg-4-791-2007, 2007.

Peters, A. J., Walter-Shea, E. A., Ji, L., Vina, A., Hayes, M., and Svoboda, M. D.: Drought monitoring with NDVI-based standardized vegetation index, Photogramm. Eng. Rem. S., 68, 7175, 2002.

Phillips, O. L., Aragao, L., Lewis, S. L., Fisher, J. B., Lloyd, J., Lopez-Gonzalez, G., Malhi, Y., Monteagudo, A., Peacock, J., Quesada, C. A., van der Heijden, G., Almeida, S., Amaral, I., Arroyo, L., Aymard, G., Baker, T. R., Banki, O., Blanc, L., Bonal, D., Brando, P., Chave, J., de Oliveira, A. C. A., Cardozo, N. D., Czimczik, C. I., Feldpausch, T. R., Freitas, M. A., Gloor, E., Higuchi, N., Jimenez, E., Lloyd, G., Meir, P., Mendoza, C., Morel, A., Neill, D. A., Nepstad, D., Patino, S., Penuela, M. C., Prieto, A., Ramirez, F., Schwarz, M., Silva, J., Silveira, M., Thomas, A. S., ter Steege, H., Stropp, J., Vasquez, R., Zelazowski, P., Davila, E. A., Andelman, S., Andrade, A., Chao, K. J., Erwin, T., Di Fiore, A., Honorio, E., Keeling, H., Killeen, T. J., Laurance, W. F., Cruz, A. P., Pitman, N. C. A., Vargas, P. N., Ramirez-Angulo, H., Rudas, A., Salamao, R., Silva, N., Terborgh, J., and Torres-Lezama, A.: Drought Sensitivity of the Amazon Rainforest, Science, 323, 1344-1347, 2009.

Piao, S., Sitch, S., Ciais, P., Friedlingstein, P., Peylin, P., Wang, X., Ahlström, A., Anav, A., Canadell, J. G., Cong, N., Huntingford, C., Jung, M., Levis, S., Levy, P. E., Li, J., Lin, X., Lomas, M. R., Lu, M., Luo, Y., Ma, Y., Myneni, R. B., Poulter, B., Sun, Z., Wang, T., Viovy, N., Zaehle, S., and Zeng, N.: Evaluation of terrestrial carbon cycle models for their response to climate variability and to $\mathrm{CO}_{2}$ trends, Glob. Change Biol., 19, 2117-2132, 2013

Piao, S. L., Friedlingstein, P., Ciais, P., de Noblet-Ducoudre, N., Labat, D., and Zaehle, S.: Changes in climate and land use have a larger direct impact than rising $\mathrm{CO}_{2}$ on global river runoff trends, Proceedings of the National Academy of Sciences of the United States of America, 104, 15242-15247, doi:10.1073/pnas.0707213104, 2007.

Piao, S. L., Fang, J. Y., Ciais, P., Peylin, P., Huang, Y., Sitch, S., and Wang, T.: The carbon balance of terrestrial ecosystems in China, Nature, 458, 1009-U1082, 2009a.

Piao, S. L., Yin, L., Wang, X. H., Ciais, P., Peng, S. S., Shen, Z. H., and Seneviratne, S. I.: Summer soil moisture regulated by precipitation frequency in China, Environ. Res. Lett., 4, 044012, doi:10.1088/1748-9326/4/4/044012, 2009b.

Piao, S. L., Ito, A., Li, S. G., Huang, Y., Ciais, P., Wang, X. H., Peng, S. S., Nan, H. J., Zhao, C., Ahlström, A., Andres, R. J., Chevallier, F., Fang, J. Y., Hartmann, J., Huntingford, C., Jeong, S., Levis, S., Levy, P. E., Li, J. S., Lomas, M. R., Mao, J. F., Mayorga, E., Mohammat, A., Muraoka, H., Peng, C. H., Peylin, P., Poulter, B., Shen, Z. H., Shi, X., Sitch, S., Tao, S., Tian, H. Q., Wu, X. P., Xu, M., Yu, G. R., Viovy, N., Zaehle, S., Zeng, N., and Zhu, B.: The carbon budget of terrestrial ecosystems in East Asia over the last two decades, Biogeosciences, 9, 3571-3586, doi:10.5194/bg-9-3571-2012, 2012.

Pisek, J., Chen, J. M., and Deng, F.: Assessment of a global leaf area index product from SPOT-4 VEGETATION data over selected sites in Canada, Can. J. Remote Sens., 33, 341-356, 2007.

Ponce Campos, G. E., Moran, M. S., Huete, A., Zhang, Y., Bresloff, C., Huxman, T. E., Eamus, D., Bosch, D. D., Buda, A. R., Gunter, S. A., Scalley, T. H., Kitchen, S. G., McClaran, M. P., McNab, W. H., Montoya, D. S., Morgan, J. A., Peters, D. P. C., Sadler, E. J., Seyfried, M. S., and Starks, P. J.: Ecosystem resilience despite large-scale altered hydroclimatic conditions, Nature, 494, 349$352,2013$.

Potter, C., Klooster, S., Hiatt, C., Genovese, V., and CastillaRubio, J. C.: Changes in the carbon cycle of Amazon ecosystems during the 2010 drought, Environ. Res. Lett., 6, 034024, doi:10.1088/1748-9326/6/3/034024, 2011.

Qin, N., Chen, X., Fu, G., Zhai, J., and Xue, X.: Precipitation and temperature trends for the Southwest China: 1960-2007, Hydrol. Process., 24, 3733-3744, 2010.

Quiring, S. M. and Ganesh, S.: Evaluating the utility of the Vegetation Condition Index (VCI) for monitoring meteorological drought in Texas, Agr. Forest Meteorol., 150, 330-339, 2010.

Reichstein, M., Tenhunen, J. D., Roupsard, O., Ourcival, J. M., Rambal, S., Miglietta, F., Peressotti, A., Pecchiari, M., Tirone, G., and Valentini, R.: Severe drought effects on ecosystem $\mathrm{CO}_{2}$ and $\mathrm{H}_{2} \mathrm{O}$ fluxes at three Mediterranean evergreen sites: revision of current hypotheses ?, Glob. Change Biol., 8, 999-1017, 2002.

Reichstein, M., Ciais, P., Papale, D., Valentini, R., Running, S., Viovy, N., Cramer, W., Granier, A., Ogee, J., Allard, V., Aubinet, M., Bernhofer, C., Buchmann, N., Carrara, A., Grunwald, T., Heimann, M., Heinesch, B., Knohl, A., Kutsch, W., Loustau, D., Manca, G., Matteucci, G., Miglietta, F., Ourcival, J. M., Pilegaard, K., Pumpanen, J., Rambal, S., Schaphoff, S., Seufert, G., Soussana, J. F., Sanz, M. J., Vesala, T., and Zhao, M.: Reduction of ecosystem productivity and respiration during the European summer 2003 climate anomaly: a joint flux tower, remote sensing and modelling analysis, Glob. Change Biol., 13, 634-651, 2007.

Running, S. W.: Climate change - Ecosystem disturbance, carbon, and climate, Science, 321, 652-653, 2008.

Running, S. W. and Coughlan, J. C.: A general model of forest ecosystem processes for regional applications 1 . hydrologic balance, canopy gas exchange and primary production processes, Ecol. Model., 42, 125-154, 1988.

Saigusa, N., Ichii, K., Murakami, H., Hirata, R., Asanuma, J., Den, H., Han, S.-J., Ide, R., Li, S.-G., Ohta, T., Sasai, T., Wang, S.Q., and Yu, G.-R.: Impact of meteorological anomalies in the 2003 summer on Gross Primary Productivity in East Asia, Biogeosciences, 7, 641-655, doi:10.5194/bg-7-641-2010, 2010. 
Samanta, A., Costa, M. H., Nunes, E. L., Vieira, S. A., Xu, L., and Myneni, R. B.: Comment on "Drought-Induced Reduction in Global Terrestrial Net Primary Production from 2000 Through 2009”, Science, 333, 1093, doi:10.1126/science.1199048, 2011.

Schwalm, C. R., Williams, C. A., Schaefer, K., Arneth, A., Bonal, D., Buchmann, N., Chen, J. Q., Law, B. E., Lindroth, A., Luyssaert, S., Reichstein, M., and Richardson, A. D.: Assimilation exceeds respiration sensitivity to drought: A FLUXNET synthesis, Glob. Change Biol., 16, 657-670, 2010a.

Schwalm, C. R., Williams, C. A., Schaefer, K., Anderson, R., Arain, M. A., Baker, I., Barr, A., Black, T. A., Chen, G., Chen, J. M., Ciais, P., Davis, K. J., Desai, A., Dietze, M., Dragoni, D., Fischer, M. L., Flanagan, L. B., Grant, R., Gu, L., Hollinger, D., Izaurralde, R. C., Kucharik, C., Lafleur, P., Law, B. E., Li, L., Li, Z., Liu, S., Lokupitiya, E., Luo, Y., Ma, S., Margolis, H., Matamala, R., McCaughey, H., Monson, R. K., Oechel, W. C., Peng, C., Poulter, B., Price, D. T., Riciutto, D. M., Riley, W., Sahoo, A. K., Sprintsin, M., Sun, J., Tian, H., Tonitto, C., Verbeeck, H., and Verma, S. B.: A model-data intercomparison of $\mathrm{CO}_{2}$ exchange across North America: Results from the North American Carbon Program site synthesis, Journal of Geophysical Research: Biogeosciences, 115, G00H05, doi:10.1029/2009jg001229, $2010 \mathrm{~b}$.

Schwalm, C. R., Williams, C. A., Schaefer, K., Baldocchi, D., Black, T. A., Goldstein, A. H., Law, B. E., Oechel, W. C., Paw U, K. T., and Scott, R. L.: Reduction in carbon uptake during turn of the century drought in western North America, Nature Geosci., 5, 551-556, 2012.

Shangguan, W., Dai, Y., Liu, B., Ye, A., and Yuan, H.: A soil particle-size distribution dataset for regional land and climate modelling in China, Geoderma, 171-172, 85-91, 2012.

Sonnentag, O., Chen, J. M., Roulet, N. T., Ju, W., and Govind, A.: Spatially explicit simulation of peatland hydrology and carbon dioxide exchange: Influence of mesoscale topography, J. Geophys. Res.-Biogeosci., 113, G02005, doi:10.1029/2007JG000605, 2008.

Sprintsin, M., Chen, J. M., Desai, A., and Gough, C. M.: Evaluation of leaf-to-canopy upscaling methodologies against carbon flux data in North America, J. Geophys. Res.-Biogeosci., 117, G01023, doi:10.1029/2010jg001407, 2012.

Sun, C. and Yang, S.: Persistent severe drought in southern China during winter-spring 2011: Large-scale circulation patterns and possible impacting factors, J. Geophys. Res.-Atmos., 117, D10112, doi:10.1029/2012jd017500, 2012.

Sun, R., Chen, J. M., Zhu, Q. J., Zhou, Y. Y., Liu, J., Li, J. T., Liu, S. H., Yan, G. J., and Tang, S. H.: Spatial distribution of net primary productivity and evapotranspiration in Changbaishan Natural Reserve, China, using Landsat ETM+ data, Can. J. Remote Sens., 30, 731-742, 2004.

Thomas, K., Sabina, D., and Mario, M.-H.: Extreme late-summer drought causes neutral annual carbon balance in southwestern ponderosa pine forests and grasslands, Environ. Res. Lett., 8, 015015, doi:10.1088/1748-9326/8/1/015015, 2013.

Tian, H. Q., Xu, X. F., Lu, C. Q., Liu, M. L., Ren, W., Chen, G. S., Melillo, J., and Liu, J. Y.: Net exchanges of $\mathrm{CO}_{2}, \mathrm{CH}_{4}$, and $\mathrm{N}_{2} \mathrm{O}$ between China's terrestrial ecosystems and the atmosphere and their contributions to global climate warming, J. Geophys. Res.Biogeosci., 116, G02011, doi:10.1029/2010jg001393, 2011a.

Tian, H. Q., Melillo, J., Lu, C. Q., Kicklighter, D., Liu, M. L., Ren, W., Xu, X. F., Chen, G. S., Zhang, C., Pan, S. F., Liu, J. Y., and Running, S.: China's terrestrial carbon balance: Contributions from multiple global change factors, Global Biogeochem. Cy., 25, GB1007, doi:10.1029/2010gb003838, 2011 b.

van der Molen, M. K., Dolman, A. J., Ciais, P., Eglin, T., Gobron, N., Law, B. E., Meir, P., Peters, W., Phillips, O. L., Reichstein, M., Chen, T., Dekker, S. C., Doubkova, M., Friedl, M. A., Jung, M., van den Hurk, B., de Jeu, R. A. M., Kruijt, B., Ohta, T., Rebel, K. T., Plummer, S., Seneviratne, S. I., Sitch, S., Teuling, A. J., van der Werf, G. R., and Wang, G.: Drought and ecosystem carbon cycling, Agr. Forest Meteorol., 151, 765-773, 2011.

Vetter, M., Churkina, G., Jung, M., Reichstein, M., Zaehle, S., Bondeau, A., Chen, Y., Ciais, P., Feser, F., Freibauer, A., Geyer, R., Jones, C., Papale, D., Tenhunen, J., Tomelleri, E., Trusilova, K., Viovy, N., and Heimann, M.: Analyzing the causes and spatial pattern of the European 2003 carbon flux anomaly using seven models, Biogeosciences, 5, 561-583, doi:10.5194/bg-5561-2008, 2008.

Vicente-Serrano, S. M., Gouveia, C., Julio Camarero, J., Begueria, S., Trigo, R., Lopez-Moreno, J. I., Azorin-Molina, C., Pasho, E., Lorenzo-Lacruz, J., Revuelto, J., Moran-Tejeda, E., and SanchezLorenzo, A.: Response of vegetation to drought time-scales across global land biomes, Proc. Natl. Ac. Sci. USA, 110, 5257, 2013.

Wang, A., Lettenmaier, D. P., and Sheffield, J.: Soil moisture drought in China, 1950-2006, J. Climate, 24, 3257-3271, 2011.

Wang, H., Zhang, R., Liu, M., and Bi, J.: The carbon emissions of Chinese cities, Atmos. Chem. Phys, 12, 6197-6206, doi:10.5194/acp-12-6197-2012, 2012a.

Wang, L., Li, C., Ying, Q., Cheng, X., Wang, X., Li, X., Hu, L., Liang, L., Yu, L., Huang, H., and Gong, P.: China's urban expansion from 1990 to 2010 determined with satellite remote sensing, Chinese Sci. Bull., 57, 2802-2812, 2012b.

Wang, Q., Tenhunen, J., Falge, E., Bernhofer, C., Granier, A., and Vesala, T.: Simulation and scaling of temporal variation in gross primary production for coniferous and deciduous temperate forests, Glob. Change Biol., 10, 37-51, 2004.

Wang, Q. F., Niu, D., Yu, G. R., Ren, C. Y., Wen, X. F., Chen, J. M., and Ju, W. M.: Simulating the exchanges of carbon dioxide, water vapor and heat over Changbai Mountains temperate broadleaved Korean pine mixed forest ecosystem, Sci. China Ser. D, 48, 148-159, 2005.

Wu, C. and Chen, J. M.: Diverse responses of vegetation production to interannual summer drought in North America, International J. Appl. Earth Observat. Geoinformat., 21, 1-6, 2013.

Wu, Z. Y., Lu, G. H., Wen, L., and Lin, C. A.: Reconstructing and analyzing China's fifty-nine year (1951-2009) drought history using hydrological model simulation, Hydrol. Earth Syst. Sc., 15, 2881-2894, 2011.

Xiao, J. F., Zhuang, Q. L., Liang, E. Y., McGuire, A. D., Moody, A., Kicklighter, D. W., Shao, X. M., and Melillo, J. M.: Twentiethcentury droughts and their impacts on terrestrial carbon cycling in China, Earth Interact., 13, 10, doi:10.1175/2009ei275.1, 2009.

Xiao, J. F., Zhuang, Q. L., Law, B. E., Baldocchi, D. D., Chen, J. Q., Richardson, A. D., Melillo, J. M., Davis, K. J., Hollinger, D. Y., Wharton, S., Oren, R., Noormets, A., Fischer, M. L., Verma, S. B., Cook, D. R., Sun, G., McNulty, S., Wofsy, S. C., Bolstad, P. V., Burns, S. P., Curtis, P. S., Drake, B. G., Falk, M., Foster, D. R., Gu, L. H., Hadley, J. L., Katulk, G. G., Litvak, M., Ma, S. Y., Martinz, T. A., Matamala, R., Meyers, T. P., Monson, R. 
K., Munger, J. W., Oechel, W. C., Paw, U. K. T., Schmid, H. P., Scott, R. L., Starr, G., Suyker, A. E., and Torn, M. S.: Assessing net ecosystem carbon exchange of U.S. terrestrial ecosystems by integrating eddy covariance flux measurements and satellite observations, Agr. Forest Meteorol., 151, 60-69, 2011.

Xu, X., Piao, S., Wang, X., Chen, A., Ciais, P., and Myneni, R. B.: Spatio-temporal patterns of the area experiencing negative vegetation growth anomalies in China over the last three decades, Environ. Res. Lett., 7, 035701, doi:10.1088/1748-9326/7/3/035701, 2012.

Yan, J., Zhang, Y., Yu, G., Zhou, G., Zhang, L., Li, K., Tan, Z., and Sha, L.: Seasonal and inter-annual variations in net ecosystem exchange of two old-growth forests in southern China, Agr. Forest Meteorol., 182-183, 257-265, 2013.

Yang, F. and Zhou, G.: Sensitivity of temperate desert steppe carbon exchange to seasonal droughts and precipitation variations in inner mongolia, china, Plos One, 8, e55418-e55418, doi:10.1371/journal.pone.0055418, 2013.

Yi, C. X., Ricciuto, D., Li, R., Wolbeck, J., Xu, X. Y., Nilsson, M., Aires, L., Albertson, J. D., Ammann, C., Arain, M. A., de Araujo, A. C., Aubinet, M., Aurela, M., Barcza, Z., Barr, A., Berbigier, P., Beringer, J., Bernhofer, C., Black, A. T., Bolstad, P. V., Bosveld, F. C., Broadmeadow, M. S. J., Buchmann, N., Burns, S. P., Cellier, P., Chen, J. M., Chen, J. Q., Ciais, P., Clement, R., Cook, B. D., Curtis, P. S., Dail, D. B., Dellwik, E., Delpierre, N., Desai, A. R., Dore, S., Dragoni, D., Drake, B. G., Dufrene, E., Dunn, A., Elbers, J., Eugster, W., Falk, M., Feigenwinter, C., Flanagan, L. B., Foken, T., Frank, J., Fuhrer, J., Gianelle, D., Goldstein, A., Goulden, M., Granier, A., Grunwald, T., Gu, L., Guo, H. Q., Hammerle, A., Han, S. J., Hanan, N. P., Haszpra, L., Heinesch, B., Helfter, C., Hendriks, D., Hutley, L. B., Ibrom, A., Jacobs, C., Johansson, T., Jongen, M., Katul, G., Kiely, G., Klumpp, K., Knohl, A., Kolb, T., Kutsch, W. L., Lafleur, P., Laurila, T., Leuning, R., Lindroth, A., Liu, H. P., Loubet, B., Manca, G., Marek, M., Margolis, H. A., Martin, T. A., Massman, W. J., Matamala, R., Matteucci, G., McCaughey, H., Merbold, L., Meyers, T., Migliavacca, M., Miglietta, F., Misson, L., Moelder, M., Moncrieff, J., Monson, R. K., Montagnani, L., Montes-Helu, M., Moors, E., Moureaux, C., Mukelabai, M. M., Munger, J. W., Myklebust, M., Nagy, Z., Noormets, A., Oechel, W., Oren, R., Pallardy, S. G., Kyaw, T. P. U., Pereira, J. S., Pilegaard, K., Pinter, K., Pio, C., Pita, G., Powell, T. L., Rambal, S., Randerson, J. T., von Randow, C., Rebmann, C., Rinne, J., Rossi, F., Roulet, N., Ryel, R. J., Sagerfors, J., Saigusa, N., Sanz, M. J., Mugnozza, G. S., Schmid, H. P., Seufert, G., Siqueira, M., Soussana, J. F., Starr, G., Sutton, M. A., Tenhunen, J., Tuba, Z., Tuovinen, J. P., Valentini, R., Vogel, C. S., Wang, J. X., Wang, S. Q., Wang, W. G., Welp, L. R., Wen, X. F., Wharton, S., Wilkinson, M., Williams, C. A., Wohlfahrt, G., Yamamoto, S., Yu, G. R., Zampedri, R., Zhao, B., and Zhao, X. Q.: Climate control of terrestrial carbon exchange across biomes and continents, Environ. Res. Lett., 5, 034007, doi:10.1088/1748-9326/5/3/034007, 2010.

Yu, G. R., Zhu, X. J., Fu, Y. L., He, H. L., Wang, Q. F., Wen, X. F., Li, X. R., Zhang, L. M., Zhang, L., Su, W., Li, S. G., Sun, X. M., Zhang, Y. P., Zhang, J. H., Yan, J. H., Wang, H. M., Zhou, G. S., Jia, B. R., Xiang, W. H., Li, Y. N., Zhao, L., Wang, Y. F., Shi, P. L., Chen, S. P., Xin, X. P., Zhao, F. H., Wang, Y. Y., and Tong, C. L.: Spatial patterns and climate drivers of carbon fluxes in terrestrial ecosystems of China, Glob. Change Biol., 19, 798-810, 2013.

Yuan, W. P., Liu, D., Dong, W. J., Liu, S. G., Zhou, G. S., Yu, G. R., Zhao, T. B., Feng, J. M., Ma, Z. G., Chen, J. Q., Chen, Y., Chen, S. P., Han, S. J., Huang, J. P., Li, L. H., Liu, H. Z., Liu, S. M., Ma, M. G., Wang, Y. F., Xia, J. Z., Xu, W. F., Zhang, Q., Zhao, X. Q., and Zhao, L.: Multiyear precipitation reduction strongly decrease carbon uptake over North China, Biogeosciences Discuss., 10, 1605-1634, doi:10.5194/bgd-10-1605-2013, 2013.

Zeng, N., Qian, H. F., Munoz, E., and Iacono, R.: How strong is carbon cycle-climate feedback under global warming?, Geophys. Res. Lett., 31, L20203, doi:10.1029/2004g1020904, 2004.

Zeng, N., Qian, H. F., Roedenbeck, C., and Heimann, M.: Impact of 1998-2002 midlatitude drought and warming on terrestrial ecosystem and the global carbon cycle, Geophys. Res. Lett., 32, L22709, doi:10.1029/2005g1024607, 2005.

Zhai, J., Su, B., Krysanova, V., Vetter, T., Gao, C., and Jiang, T.: Spatial variation and trends in PDSI and SPI indices and their relation to streamflow in 10 large regions of China, J. Climate, 23, 649-663, 2010.

Zhang, A. and Jia, G.: Monitoring meteorological drought in semiarid regions using multi-sensor microwave remote sensing data, Remote Sens. Environ., 134, 12-23, 2013.

Zhang, C., Ju, W., Chen, J. M., Zan, M., Li, D., Zhou, Y., and Wang, $\mathrm{X}$.: China's forest biomass carbon sink based on seven inventories from 1973 to 2008, Clim. Change, 118, 933-948, 2013.

Zhang, F., Ju, W., Chen, J., Wang, S., Yu, G., Li, Y., Han, S., and Jun, A.: Study on evapotranspiration in East Asia using the BEPS ecological model, J. Nat. Resour., 25, 1596-1606, 2010.

Zhang, F., Chen, J. M., Chen, J., Gough, C. M., Martin, T. A., and Dragoni, D.: Evaluating spatial and temporal patterns of MODIS GPP over the conterminous U.S. against flux measurements and a process model, Remote Sens. Environ., 124, 717-729, $2012 \mathrm{~b}$.

Zhang, F., Ju, W., Shen, S., Wang, S., Yu, G., and Han, S.: Variations of terrestrial net primary productivity in East Asia, Terr. Atmos. Ocean Sci., 23, 425-437, 2012c, http://www.ocean-sci.net/23/425/2012/.

Zhang, L., Xiao, J., Li, J., Wang, K., Lei, L., and Guo, H.: The 2010 spring drought reduced primary productivity in southwestern China, Environ. Res. Lett., 6, 045706, doi:10.1088/17489326/6/4/045508, 2012a.

Zhang, Y. Q. and Wegehenkel, M.: Integration of MODIS data into a simple model for the spatial distributed simulation of soil water content and evapotranspiration, Remote Sens. Environ., 104, 393-408, 2006.

Zhao, M. and Running, S. W.: Drought-induced reduction in global terrestrial net primary production from 2000 through 2009, Science, 329, 940-943, 2010.

Zou, X. K., Zhai, P. M., and Zhang, Q.: Variations in droughts over China: 1951-2003, Geophys. Res. Lett., 32, L04707, doi:10.1029/2004g1021853, 2005. 